Western New England University School of Law

Digital Commons @ Western New England University School of

Law

Faculty Scholarship

Faculty Publications

2017

\title{
Blurred Lines-Intersexuality and the Law: An Annotated Bibliography
}

Pat Newcombe

Western New England University School of Law, pnewcombe@law.wne.edu

Follow this and additional works at: https://digitalcommons.law.wne.edu/facschol

Part of the Law and Gender Commons, and the Legal Writing and Research Commons

\section{Recommended Citation}

Pat Newcombe, Blurred Lines--Intersexuality and the Law: An Annotated Bibliography, 109 LAW LIB. J. 221 (2017).

This Article is brought to you for free and open access by the Faculty Publications at Digital Commons @ Western New England University School of Law. It has been accepted for inclusion in Faculty Scholarship by an authorized administrator of Digital Commons @ Western New England University School of Law. For more information, please contact pnewcombe@law.wne.edu. 


\section{Blurred Lines-Intersexuality and the Law: An Annotated Bibliography*}

Pat Newcombe $e^{\star \star}$

This bibliography gathers, organizes, and annotates relevant law review articles (and one monograph) dealing with legal issues concerning intersexuality. Articles are included to introduce researchers to the intricacies involved in the discussion of intersexuality, to examine issues of medical interventions, and to explore possibilities of judicial relief within the existing framework.

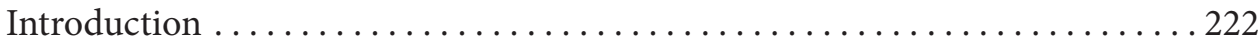

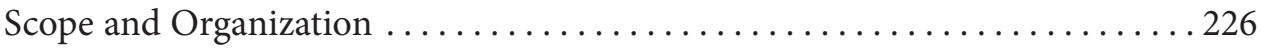

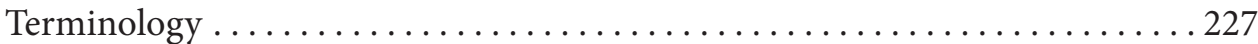

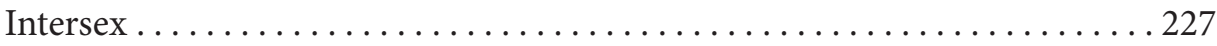

Disorders/Differences of Sex Development . . . . . . . . . . . . . . . 229

Hermaphrodite .................................... 229

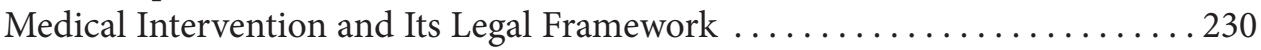

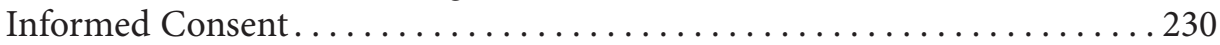

Medical Malpractice . . . . . . . . . . . . . . . . . . . . . . . . . 230

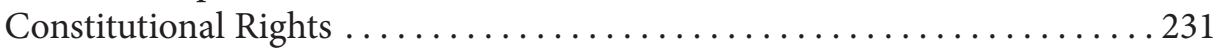

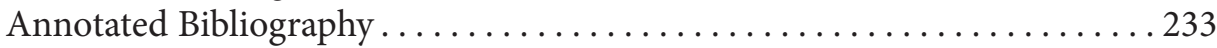

Confines of a Binary System. . . . . . . . . . . . . . . . . . 236

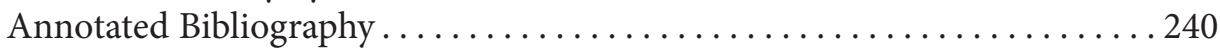

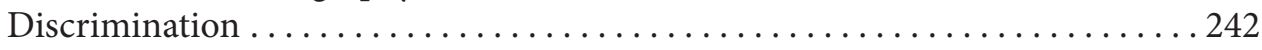

Discrimination Generally. . . . . . . . . . . . . . . . . . . . . . 242

Annotated Bibliography. ........................ 242

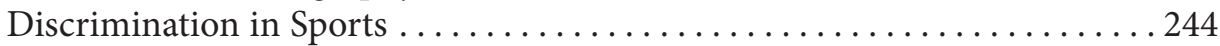

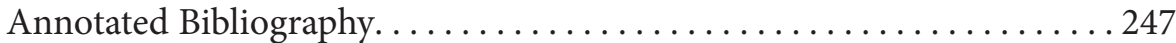

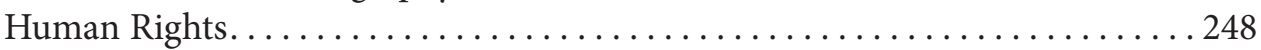

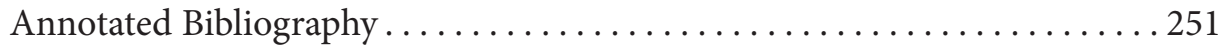

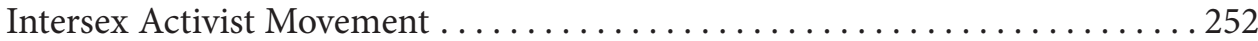

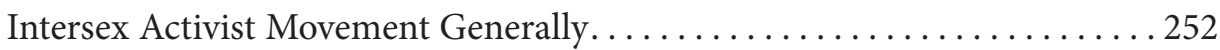

* C Pat Newcombe, 2017. Many thanks to my colleagues Sudha Setty and Beth Cohen for reviewing this article and providing thoughtful comments and feedback. I am also grateful to my colleague Jennifer Levi for sending my article for review by Julie Greenberg, an internationally recognized legal expert in the field of intersexuality. I am indebted to Julie for her advice and inspiration. A special thanks to my research assistant, Kathryn Mullin, for her assistance with this project. Responsibility for any errors is mine alone. Additionally, I am most grateful for the work my excellent library staff does that makes it possible for me to pursue writing projects.

** Associate Professor of Law and Associate Dean for Library and Information Resources, Western New England University School of Law, Springfield, Massachusetts. 
Annotated Bibliography............................. 253

Intersection with Other Movements: LGBT and Same-Sex Marriage. ...... 254

Annotated Bibliography............................... 255

Foreign Approaches to Intersex Rights........................ 257

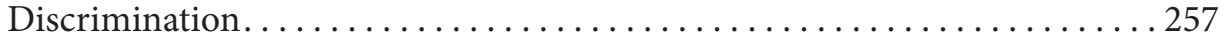

Genital Surgery Practices.............................. 258

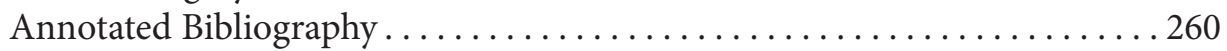

U.S. Reform/Recommendations............................. 262

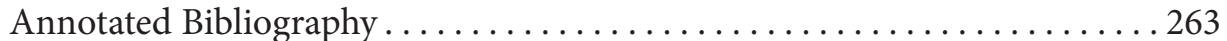

Conclusion .........................................267

\section{Introduction}

$\mathbb{1 1}$ Boy or girl? This is often the first question upon the birth of a child or upon learning of a pregnancy.

I2 "Intersex" is an umbrella term for a variety of congenital conditions that lead to ambiguity about an individual's biological sex. The physical effects can be subtle or clear. While genital ambiguity is the most obvious manifestation, intersex can present genetically, hormonally, or anatomically, as when internal reproductive or sexual anatomy does not conform to standard definitions of male or female. ${ }^{1}$ From the late nineteenth to the early twentieth centuries, physicians determined sex solely based on an individual's gonads: an individual with ovaries was considered a female, and an individual with testicles was considered a male. ${ }^{2}$ By the 1950 s, the focus of sex determination moved to the appearance of the external genitalia. ${ }^{3}$ Physicians considered intersexuality discovered at birth as an emergency requiring surgical intervention to "normalize" genitalia in affected infants to mitigate the stigma that may be associated with being perceived as sexually variant. ${ }^{4}$ There were two reasons for this development. First, physicians developed surgical methods to alter genitalia to look cosmetically consistent for the assigned sex. Second, it became a pervasive belief among the medical establishment that one's gender identity was dependent on nurture not nature. ${ }^{5}$ Doctors did not believe that infants had an innate sense of being male or female; rather, this was learned behavior. Researchers theorized that if early genital-normalization surgery enabled parents to raise their child as the sex that matched the child's genitals, the child would not

1. Hida Viloria, What Is Intersex?, OII-USA, http://oii-usa.org/1128/intersex/ [https://perma.cc /X24Q-K2P6]; see infra "Terminology," III 14-21, for a more complete definition.

2. Julie A. Greenberg, Intersexuality and the LaW: Why Sex Matters 15 (2012).

3. $I d$.

4. Id. at 15-17; see also Am. Acad. of Pediatrics, Evaluation of the Newborn with Developmental Anomalies of the External Genitalia, 106 Pediatrics 138, 138 (2000) ("The birth of a child with ambiguous genitalia constitutes a social emergency."). Surgery other than genital-normalization surgery may be medically necessary at times, however, to assist in bowel and bladder activity or when there is a risk of cancer, such as with nonfunctional testes. Catherine L. Minto et al., Long Term Sexual Function in Intersex Conditions with Ambiguous Genitalia, 14 J. Pediatric \& Adolescent GyNeCOLOGY 141, 141-42 (2001).

5. See, e.g., Joan G. Hampson et al., Hermaphrodism: Recommendations Concerning Case Management, 16 J. Clinical Endocrinology \& Metabolism 547 (1956). 
suffer gender identity confusion in spite of any differences in chromosomes or hormones. ${ }^{6}$

I3 Without surgery, physicians were concerned that “abnormal” genitalia would make a child suffer deep psychological distress. ${ }^{7}$ Physicians also believed that intersex genitalia made people uncomfortable and that parents would not be able to accept or bond with their intersex children unless the ambiguity was "erased" with such surgery. ${ }^{8}$ Because there was much stigma and shame surrounding this atypical condition, many families kept the condition secret. Parents were often told halftruths about their child's condition and were advised never to tell the child about his or her condition. ${ }^{9}$ Genital-normalization surgery became the standard of medical care for intersex infants. The choice, traditionally, has been which sex to assign to the baby, not whether to perform genital-normalization surgery. ${ }^{10}$

I4 By the late 1990s, this medical protocol was challenged by intersex activists and experts in various disciplines, including law. ${ }^{11}$ Studies confirmed that one's sense of being male or female relates more to brain and hormonal functions than the cosmetic appearance of one's genitals, and therefore if the surgically altered genitalia did not conform to the child's own sense of being male or female, a child would be greatly harmed. ${ }^{12}$ Additional evidence established that the irreversible surgical procedures had troubling risks, supported by numerous personal accounts of individuals with intersex traits who felt permanently scarred and traumatized. ${ }^{13}$ The procedures may have serious permanent effects, including sterility, a loss or diminishment of the ability to experience sexual pleasure, chronic pain or pain associated with dilation of a surgically created vagina, incontinence, lifetime mental suffering, ${ }^{14}$ and impairment

6. Alice Domurat Dreger, Ambiguous Sex-Or Ambivalent Medicine? Ethical Issues in the Treatment of Intersexuality, HASTINGS CTr. Rep., May/June 1998, at 24.

7. Hazel Glenn Beh \& Milton Diamond, An Emerging Ethical and Medical Dilemma: Should Physicians Perform Sex Assignment Surgery on Infants with Ambiguous Genitalia?, 7 Mich. J. Gender \& L. 1, 43-46 (2000).

8. Id. at $44-45$.

9. Julie A. Greenberg, Health Care Issues Affecting People with an Intersex Condition or DSD: Sex or Disability Discrimination?, 45 Loy. L.A. L. Rev. 849, 859 (2012).

10. Emily Greenhouse, A New Era for Intersex Rights, New Yorker (Dec. 30, 2013), http://www .newyorker.com/news/news-desk/a-new-era-for-intersex-rights [https://perma.cc/GM56-U4W8].

11. GreenberG, supra note 2, at 19.

12. Id. Dr. John Money's nurture over nature theory was debunked in 1997, when it was discovered that what he reported as a "successful" experiment with his test of behavioralism was actually a lie. Id. See also Milton Diamond \& H. Keith Sigmundson, Sex Reassignment at Birth: Long-Term Review and Clinical Implications, 151 Archives Pediatric \& Adolescent Med. 298, 300 (1997).

13. Mireya Navarro, When Gender Isn't a Given, N.Y. Times (Sept. 19, 2004), http://www.nytimes .com/2004/09/19/fashion/when-gender-isnt-a-given.html [https://perma.cc/E7RU-MNKS]; see also Laura Hermer, Paradigms Revised: Intersex Children, Bioethics \& the Law, 11 Annals Health L. 195, 212-13 (2002) (stating that many individuals in one of the largest studies experienced psychological and identity issues).

14. Many of these children suffer from depression, and some consider suicide as adults. There are many personal accounts, such as Jim Ambrose's, who had an X and $\mathrm{Y}$ chromosome, but had surgery as an infant to have his genitals appear more female-like. He later took female hormones and had a vagina constructed. Jim obtained his medical records when he was an adult and discovered the circumstances of his birth. As an adult, he began to take testosterone shots and had surgery to remove his breasts. Greenhouse, supra note 10. Jim's father remembers that the doctors did not make it appear as if there was much of a choice when Jim was an infant. The doctors said they could simply fix the problem. When Jim discovered that he was born intersex, Jim's parents told Jim that they felt that were doing the best thing for him, but Jim was very angry about it. Id. 
of the parent-child relationship. ${ }^{15}$ In fact, the growing consensus was that no compelling evidence supports a finding that the presumed social benefits of such "normalizing" surgery outweigh the potential costs. ${ }^{16}$

I5 Intersex activists advise against nonconsensual genital-normalization surgery and counsel acceptance for affected children. It is perhaps an expected continuance of the gender-blurring evolution. Feminism and the gay and transgender rights movements have smoothed the path for greater acceptance of individuals who do not conform to the standard male or female model. Although the general public is often confused by the difference between intersex conditions and gender identity issues, they are quite distinct. As a starting point, reference to one's gender identity describes the individual's internal, deeply held sense of his or her identity as male or female, or neither; intersex involves biological characteristics.

I6 Currently, advocates are advancing efforts to alter the approach taken in planning healthcare for children with intersex traits. For example, the Gender and Sex Development program at Chicago's Ann \& Robert H. Lurie Children's Hospital, launched three years ago, is one of several U.S. programs that uses a collaborative multidisciplinary care team of specialists experienced in this area: pediatric endocrinologists, urologists, surgeons, nurses, genetic counselors, neonatologists, pediatric gynecologists, ethicists, and child psychologists. ${ }^{17}$ The team works to assist families in weighing their options, including whether surgery should be contemplated at all.

I7 There is an increasing awareness of intersexuality today, which has led more families to explore treatment options. The new treatment approach results partially from a 2006 Consensus Statement on Intersex Disorders by U.S. and European medical specialists and intersex advocates who met to consider treatment protocols, including genital-normalization surgery. ${ }^{18}$ The Consensus Statement advocated a more cautious approach before proceeding with genital surgery, noting the resulting impact to quality of life, such as decreased sexual sensitivity. It also noted that evidence for early genital-normalizing surgery is not substantiated; promoted a more open dialog between patients and families, along with the provision of psychosocial support; and encouraged patients' and families' participation in decision making. ${ }^{19}$ Although this Consensus Statement was a step in the right direction, it

15. "If such interventions are performed solely with a view to integration of the child into its family and social environment, then they run counter to the child's welfare. In addition, there is no guarantee that the intended purpose (integration) will be achieved." Swiss NAT'L Advisory Comm'N on Biomedical Ethics, On the Management of Differences of Sex Development: Ethical Issues Relating to "Intersexuality" 13 (Opinion No. 20/201, Nov. 2012), http://www.nek-cne.ch/file admin/nek-cne-dateien/Themen/Stellungnahmen/en/NEK_Intersexualitaet_En.pdf [https://perma .cc/DC6E-KGEA].

16. Greenberg, supra note 9 , at 864 . There is still an absence of consistent psychosocial followup. Lih-Mei Liao et al., Parental Choice on Normalising Cosmetic Genital Surgery: Between a Rock and a Hard Place, 351 BMJ h5124, h5124 (Sept. 28, 2015), http://aisdsd.org/wp-content/uploads/2015/10 /Liao-creighton-2015-bmj.h5124.full_.pdf.

17. Differences of Sex Development, Anne \& Robert H. Lurie Children's Hosp. of Chi., https:// www.luriechildrens.org/en-us/care-services/conditions-treatments/disorders-of-sex-development /Pages/index.aspx [https://perma.cc/R6JX-995F].

18. Peter A. Lee et al., Consensus Statement on Management of Intersex Disorders, 118 PEDIATRICS e488, e488 (2006).

19. Id. at 490 . 
did not recommend a cessation of genital-normalization surgeries, a point that activists criticize.

I8 The Consensus Statement recommendations are a natural outgrowth of the patients' rights movement in U.S. medicine toward better communication between doctors and patients treatment that is more patient-focused. With intersex conditions, communication between doctors and parents/patients is particularly laden with emotion and controversy, and not all families are ready to accept a change in treatment philosophy. Even after advisement on the risks and concerns of genitalnormalization surgery, some families still opt for the surgery due to deep-seated concerns that their children will be considered abnormal if they fail to take any immediate action. ${ }^{20}$ Unfortunately, genital-normalization surgery has a long history of acceptance in healthcare, and even after the 2006 Consensus Statement there was no abrupt change in medical practices. ${ }^{21}$ The Chicago consensus "does not seem to have percolated down to frontline care in many cases." 22

II9 In 2016, there was an update to the 2006 Consensus Statement. ${ }^{23}$ Most significant is that the update notes that physicians working with families should be aware that there has been movement in recent years for legal and human rights bodies to increasingly emphasize the importance of maintaining patient autonomy. It also encourages that peer support be provided on a routine basis at the earliest possible time for parents, and integrated with clinical care to ease parental distress. Care recommendations include the use of a team approach, full disclosure to patients and parents, and a focus on the best possible outcome for quality of life. ${ }^{24}$

$\mathbb{1 1 0}$ Many physicians in the United States still regard genital-normalization surgery as necessary to avoid psychological damage, and data supports that there is little change in practice. ${ }^{25}$ "There is still no consensual attitude regarding indications, timing, procedure and evaluation of outcome" of this surgery. ${ }^{26}$ The perceived visibility of the intersex condition, along with the standardized reaction from the medical community and an expectant society has put much pressure on

20. Sarah M. Creighton et al., Childhood Surgery for Ambiguous Genitalia: Glimpses of Practice Changes or More of the Same?, 5 Psychol. \& Sexuality 34, 41 (2014).

21. There have been few reviews on the effect of the 2006 Consensus Statement, clitoral surgeries on children under the age of fourteen have increased since 2006, and "recent publications in the medical literature tend to focus on surgical techniques with no reports on patient experiences." Id. at 38 .

22. Martha Henriques, Intersex: Seeking the Beauty in Difference, MosaIC: The SCIENCE OF LIFE (Oct. 4, 2016), https://mosaicscience.com/story/intersex-DSDs [https://perma.cc/GA2E-FWXZ ?type=image].

23. Peter A. Lee et al., Global Disorders of Sex Development Update Since 2006: Perceptions, Approach and Care, 85 Hormone Res. Paediatrics 158 (2016).

24. Id. at $160,169-70$.

25. Alice Dreger, Malta Bans Surgery on Intersex Children, The Stranger: SLOG (Apr. 3, 2015), http://www.thestranger.com/blogs/slog/2015/04/03/22001053/malta-bans-surgery-on-intersex -children [https://perma.cc/8AL5-3ZY9]; see also Ellen K. Feder \& Alice Dreger, Still Ignoring Human Rights in Intersex Care, 12 J. Pediatric URology 436 (2016) (noting that issues have not progressed over the last twenty years, with clinical evidence still lacking and the standard of care remaining substantially the same).

26. Lee et al., supra note 23 , at 176 . Another 2016 publication reiterated numerous similar assertions from the update, but eliminated mention of human rights concerns. Pierre D.E. Mouriquand et al., Surgery in Disorders of Sex Development (DSD) with a Gender Issue: If (Why), When, and How?, 12 J. Pediatric Urology 139 (2016). 
physicians and parents to take an aggressive and intrusive approach at an early age. However, it is possible that we are on the very brink of a sea change in the medical standard of care, as surgical practices have become a controversial issue in public and professional discussion, and as we now see legal and human rights institutions increasingly focus on patient autonomy.

\section{Scope and Organization}

I11 This annotated bibliography offers a survey of law review articles (and one monograph $)^{27}$ to introduce researchers and scholars to the issues involved in the discussion of intersexuality and the law. ${ }^{28}$ Although there is limited scholarship in this area, it is a topic of burgeoning interest, and it is useful to review and update existing scholarship. The annotations include a brief summary of a particular focus within each article. In this way, the breadth of available scholarship in a wide variety of subject areas is provided. Before each grouping of annotations is an overview of each topic incorporating any available updated information.

I12 Searching for legal literature on intersexuality requires the use of multiple words and phrases to describe the issues. All of the search terms listed below were used in compiling this annotated bibliography. The selected articles were compiled by conducting Westlaw searches using the following search terms in the title field: intersex!, hermaphrodit!, "genital normaliz!," assign! / 3 sex, disorder / 2 "sex development," difference /2 "sex development," DSD, sexing /4 child!, "third gender," "ambigu! /2 sex, and "ambiguous genital!"29

$\mathbb{1 1 3}$ Since this issue is an evolving one of increasing awareness, articles are from 2001 to the present. This annotated bibliography is divided into sections that cover resources that provide a background on the medical intervention for individuals with intersex traits and its legal framework, the confines of treating gender as a binary system, discrimination against intersex individuals, the human rights issues surrounding intersexuality, the impact of the intersex activist movement, some foreign approaches to intersexuality, and possible U.S. judicial and statutory reforms. Within each section, the items are arranged alphabetically by author.

27. Greenberg, supra note 2. This title is included as it is the sole monograph that focuses on the role that legal institutions can play in protecting the rights of people with intersex traits, and it is a very highly regarded work.

28. Much cutting-edge work on the topic of intersexuality is published in nonlegal journals. Although I am focusing on law review literature in this article, it is important to note that there are excellent articles in, for example, medical journals that delve into legal issues, which researchers would be wise to examine.

29. All the annotated articles resulted from this search, except for one outlier written by one of the leading experts on the topic of sex testing and sports policies that ban women athletes for having naturally high testosterone. Katrina Karkazis et al., Out of Bounds? A Critique of the New Policies on Hyperandrogenism in Elite Female Athletes, Aм. J. Bioethics, July 2012, at 3. 


\section{Terminology}

\section{Intersex ${ }^{30}$}

I14 At birth, infants are classified as male or female, usually determined by the presentation of their external anatomy. In reality, however, an individual's sex is a combination of bodily characteristics that comprises chromosomes, genitals, hormones, and gonads. If any of these do not fit typical definitions of male or female, they can result in additional variations in secondary sexual characteristics such as muscle mass, hair distribution, breast development, hip-to-waist ratio, and stature. ${ }^{31}$ All of these factors encompass the wide array of variations in sex characteristics in intersexuality.

I15 Medical science has progressed so that we now have a greater understanding of the origins of intersexuality. Genetic male and female embryos are anatomically identical through the first six to seven weeks of gestation. ${ }^{32}$ After that, hormonal and genetic influences trigger the beginning of development of testes or ovaries. ${ }^{33}$ However, hormonal and genetic occurrences in the womb may cause biological variation so that at birth, chromosomes, hormones, gonads, or external anatomy do not correspond to the typical male or female.

I16 These hormonal and genetic occurrences may cause an intersex individual to be born with one of several medical conditions that lead to the individual's biological sex being ambiguous. For example, an infant may be born with genitalia that have characteristics of both males and females. A female child may be born with an unusually large clitoris or without a vaginal opening; a male child may be born with a micropenis or with a scrotum that is divided in the formation typical of labia.

I17 However, not all intersex conditions involve ambiguous genitalia, so they may not be immediately identified at birth. Some individuals with intersex traits have external genitals of one sex, but the internal anatomy of the other sex. Some individuals have the chromosomes of one sex, but the sexual anatomy of the opposite sex. Some may possess male genitals, small testes, and ovaries. Others may have atypical chromosomal configurations, such as XXX or XXY or XYY, while some may have different chromosomal compositions in different tissues, a condition referred to as mosaicism. There is an array of congenital conditions including,

30. The term "intersexuality" was coined by Richard Goldschmidt in his 1917 article Intersexuality and the Endocrine Aspect of Sex, 1 ENDOCRINOLOGY 433 (1917). Throughout the accompanying text in this annotated bibliography, I use the term "intersex," and, when referencing individuals, I use the term "individuals with intersex traits," so as to avoid labeling individuals with a term of a biological condition. When annotating articles, I use the specific term the author used.

31. Viloria, supra note 1.

32. Exploring the Biological Contributions to Human Health: Does Sex Matter? 45 (Theresa M. Wizemann \& Mary-Lou Pardue eds., 2001).

33. Am. Acad. of Pediatrics, supra note 4, at 138. 
among others, hypospadias, ${ }^{34}$ Turner syndrome, ${ }^{35}$ congenital adrenal hyperplasia, ${ }^{36}$ complete androgen insensitivity syndrome (CAIS) ${ }^{37}$ partial androgen insensitivity syndrome (PAIS), ${ }^{38}$ and 5-alpha-reductase deficiency (5-ARD). ${ }^{39}$

I18 Doctors' assessments about what specific conditions should be classified as intersex has been controversial..$^{40}$ Due to this lack of consensus, and the various terms used to refer to intersex, estimates for the prevalence of intersex conditions are not exact. Medical experts, however, estimate that when looking at the number of infants born with visibly anomalous genitalia that prompts medical investigation, the average is about 1 in 2000 births, or $0.05 \%$ of births. ${ }^{41}$ However, some advocates believe many more people are born with more subtle types of sex variations than ambiguous genitalia, which are not discovered upon birth, and that they constitute $1.7 \%$ of births. ${ }^{42}$ Sometimes intersexuality does not come to light until puberty ${ }^{43}$ or during later stages in development, such as when adults find that they

34. Hypospadias is a condition in which individuals with XY chromosomes have the urinary opening of the penis located somewhere along the underside of the penis, instead of the tip. The severity of hypospadias can vary; sometimes it is such that the penis resembles labia. This can occur as an isolated symptom in men with otherwise typical sex development or in conjunction with other intersex conditions. Hypospadias, ISNA: INTERSEX SOC'y OF NORTH AM., http://www.isna.org/faq /conditions/hypospadias [https://perma.cc/W2WZ-PSFZ]. Although ISNA became defunct in 2008, this informative website remains accessible for historical purposes. Dear ISNA Friends and Supporters, ISNA: INTERSEX SOC'y OF NorTH AM., http://www.isna.org/ [https://perma.cc/GX27-DYGD].

35. Turner syndrome is a chromosomal condition in which girls have only one $\mathrm{X}$ chromosome; female sex characteristics exist but are immature in comparison to the average female. Turner Syndrome, ISNA: INTERSEX SOC'y OF NORTH AM., http://www.isna.org/faq/conditions/turner [https:// perma.cc/DL2L-BFKM].

36. In congenital adrenal hyperplasia, the adrenal glands cannot produce cortisol, causing a large production of other hormones that cause virilization. Infants with XX chromosomes may develop larger than average clitorises, or even a clitoris that resembles a penis, or labia that appear more like a scrotum. Congenital Adrenal Hyperplasia (CAH), ISNA: INTERSEX Soc'y OF NORTH AM., http://www .isna.org/faq/conditions/cah [https://perma.cc/7YDM-NC8D].

37. Complete androgen insensitivity syndrome (CAIS) is a genetic condition in which, because of a receptor defect, the body is unable to process the testosterone produced by the testes, so the body develops as female. CAIS individuals have XY chromosomes and a short vagina or none at all. External female genitalia form, but no internal female reproductive organs develop. Individuals with CAIS have undescended or partially descended testes. Melissa Hines et al., Psychological Outcomes and Gender-Related Development in Complete Androgen Insensitivity Syndrome, 32 ARCHIVEs SeXUAL BEHAV. 93, 93 (2003). Most individuals with CAIS never learn the reason they do not menstruate or are unsuccessful in becoming pregnant. Sharon E. Preves, Out of the O.R. and into the Streets: Exploring the Impact of Intersex Media Activism, 12 CARDOZO J.L. \& GENDER 247, 249-50 n.7 (2005).

38. In contrast, individuals with partial androgen insensitivity syndrome (PAIS) are able to partially process testosterone, so their genitals will masculinize to a certain extent. Greenberg, supra note 9 , at 854 n.6.

39. An enzyme deficiency, 5-alpha-reductase deficiency (5-ARD) results in XY genetic individuals who most often appear to be females when born, but virilize at puberty when testosterone increases. What Is 5-Alpha-Reductase Deficiency (5-ARD)?, AcCord Alliance, http://www.accordalliance.org /faqs/what-is-5-alpha-reductase-deficiency-5-ard/ [https://perma.cc/BW3Y-XGLX]. Children are often raised as girls, but usually come to have a male gender identity.

40. Elisabeth McDonald, Intersex People in Aotearoa New Zealand: The Challenges for Law and Social Policy Part I: Critiquing Gender Normalising Surgery, 46 Victoria U. Wellington L. Rev. 705, 707 (2015).

41. Hida Viloria, How Common Is Intersex? An Explanation of the Stats., OII-USA, http://oii-usa .org/2563/how-common-is-intersex-in-humans/ [https://perma.cc/CEC5-ZPHF].

42. Id.

43. For example, if a doctor does not know that an infant who possesses typical female genitals 
are infertile. Sometimes individuals are determined to have an intersex condition only upon autopsy. Others live all their lives with intersex conditions without anyone knowing it, including themselves.

\section{Disorders/Differences of Sex Development}

I19 A more recent term used to connote intersexuality in the medical community is "disorders of sexual development" (DSD). This term is defined by the 2006 Consensus Statement on Intersex Disorders as "congenital conditions in which development of chromosomal, gonadal, or anatomic sex is atypical." ${ }^{44}$ Accord Alliance, an advocacy organization, notes that older terms such as "hermaphrodite" and "intersex" are not preferred because the terms are imprecise, and label individuals, not specific medical conditions. ${ }^{45}$

\20 The term "disorder" of sex development is itself a controversial term, ${ }^{46}$ even though it is the most common term used in the medical literature now. Individuals with intersex traits, activists, and academics have challenged the use of the term "DSD" with its designation as a "disorder," viewing this as offensive to those who feel there is nothing wrong with them and feel stigmatized by the medical connotations. ${ }^{47}$ An alternative term suggested, which uses the same acronym "DSD," is "differences of sex development." ${ }^{38}$ Many individuals with intersex traits still choose to embrace the term "intersex," however, as the term "DSD" simply contributes to pathologizing their reality and indicates the need for a medical "cure." ${ }^{9}$

\section{Hermaphrodite ${ }^{50}$}

\$21 Individuals with intersex traits were formerly referred to as "hermaphrodites," an outdated term that is both misleading and stigmatizing, ${ }^{51}$ although some

has testes within her abdominal cavity, it will likely not be until puberty that the condition will be detected, upon failure to menstruate. Greenberg, supra note 9, at 854 .

44. Lee et al., supra note 18, at e488.

45. Disorders of Sex Development, Accord Alliance (Aug. 1, 2013), http://www.accordalliance .org/glossary/disorders-of-sex-development/ [https://perma.cc/8ZKX-TADD].

46. Georgiann Davis, Contesting Intersex: The Dubious Diagnosis 87-89 (2015).

47. Ellen K. Feder, Imperatives of Normality: From "Intersex" to "Disorders of Sex Development," 15 GLQ: J. LesBian \& GAY Stud. 225, 225-26 (2009). This is ironic in light of the fact that the Intersex Society of North America (ISNA), a now defunct organization, originally used the term "DSD" specifically to support improved medical care for those born with such conditions. Why Is ISNA Using "DSD"?, ISNA: INTERSEX SOC'Y OF NoRTH AM. (May 24, 2006), http://www.isna.org/node/1066 [https:// perma.cc/9KVJ-MDK6].

48. Milton Diamond \& Hazel G. Beh, Changes in the Management of Children with Intersex Conditions, 4 Nature Clinical Prac.: Endocrinology \& Metabolism 4, 5 (2008).

49. Robert Hupf, Allyship to the Intersex Community on Cosmetic, Non-Consensual Genital "Normalizing" Surgery, 22 WM. \& MARY J. WOMEN \& L. 73, 77 (2015); see also interACT Statement on Intersex Terminology, INTERACT, http://interactadvocates.org/interact-statement-on-intersex-terminology/ [https://perma.cc/7BHU-X373?type=image].

50. The term "hermaphrodite" was named after the mythological Greek figure Hermaphroditus, "the product of a union between Hermes and Aphrodite." Jessica L. Adair, In a League of Their Own: The Case for Intersex Athletes, 18 SpoRTs Law. J. 121, 124 (2011).

51. What Is Useful About the Terminology of DSD? What Is Unhelpful?, Accord Alliance, http://www.accordalliance.org/faqs/what-is-useful-about-the-terminology-of-dsd-what-is-unhelpful [https://perma.cc/UB8B-5SHF]. In the 1940s, British specialist A.P. Cawadias made the first recommendation to substitute the term "hermaphrodite" with "intersex." A.P. CAWAdias, Hermaphroditos: THE HuMAN INTERSEX 6 (1943). 
use the term as a form of reclamation. ${ }^{52}$ The term "hermaphrodite" is from mythology, conveying that an individual is both thoroughly male and thoroughly female (an anatomical impossibility). ${ }^{53}$ The term has been used to identify those with both testicular and ovarian tissue (ovotestes). ${ }^{54} \mathrm{Up}$ until the mid-twentieth century, the term "hermaphrodite" was used to refer to all individuals with intersex traits, but it is no longer an accurate term as it refers only to a distinct observable gonadal anatomy of an individual. The term "intersex" refers to a much more complex array of permutations involving both physical appearance and genetic makeup.

\section{Medical Intervention and Its Legal Framework}

I22 Some scholars have suggested litigation as a way to protect, and to achieve justice for, infants with intersex traits. This includes the use of the informed consent doctrine, medical malpractice, and constitutional rights. Examining the various legal strategies is critical, as individuals with intersex traits who have had their rights violated require a legal avenue for effective remedy, including redress and compensation.

\section{Informed Consent}

I23 The informed consent doctrine requires that physicians must disclose all pertinent information about medical procedures and the alternatives, including no treatment at all, and must ensure that parents understand. However, because many intersex conditions are not legitimate medical emergencies, the normalization surgeries themselves are not medically necessary and may therefore mislead an intersex infant's parent(s) into consenting to surgery that would make true, "informed" consent absent. ${ }^{55}$

\section{Medical Malpractice}

I24 A medical malpractice strategy is another option discussed by scholars. However, it may be argued that the doctors followed standard medical practice when they performed genital-normalization surgery. ${ }^{56}$ Because the medical establishment determines the medical standard of care, proving that a specific standard of care is negligent presents many challenges.

I25 The medical malpractice strategy may have only a slight possibility of success in those jurisdictions that no longer follow the customary practice standard; these jurisdictions may assert that the customary practice might itself be negligent, and adopt a reasonableness standard instead. ${ }^{57}$ In those jurisdictions where physicians can no longer be sheltered by the customary practice standard, the trier of

52. Hupf, supra note 49 , at 78.

53. Is a Person Who Is Intersex a Hermaphrodite?, ISNA: INTERSEx Soc'y OF NorTH Am., http:// www.isna.org/faq/hermaphrodite [https://perma.cc/EDT6-U6VH].

54. Adair, supra note 50, at 128.

55. Liao et al., supra note 16 , at 1 (noting that parents are strongly affected by medical advice, may not be aware that they are consenting to experimental surgeries, and may experience a high level of regret).

56. Beh \& Diamond, supra note 7 , at 2 .

57. Darra L. Clark Hofman, Male, Female, and Other: How Science, Medicine and Law Treat the Intersexed, and the Implications for Sex-Dependent Law, 21 Tul. J.L. \& SEXuality 1, 14-15 (2012). 
fact must balance the comparative risks of a medical procedure and avoidance of the procedure without any expert testimony. ${ }^{58}$ The trier of fact, of course, is subject to the same societal influences regarding gender norms as the doctors who perform genital-normalization surgeries, and therefore this medical malpractice strategy may not be fruitful. ${ }^{59}$

\section{Constitutional Rights}

\$26 Nonconsensual genital-normalization surger $y^{60}$ potentially infringes on the fundamental rights of a child with intersex traits in various ways. Due to the fact that the surgeries cause irreversible damage to intersex children's physical bodies, and often leave them sterile, the fundamental rights to bodily integrity and procreation may be infringed. ${ }^{61}$ The U.S. Supreme Court should recognize and safeguard the individual right to freedom from these damaging and nonessential surgeries. Despite these considerations, current U.S. jurisprudence does not sufficiently address the many injuries experienced by individuals with intersex traits. ${ }^{62}$

\$27 While there has been some success internationally in litigation in this area, ${ }^{63}$ access to reparation in the United States is as yet unknown, as no federal case

58. Id. at 15 .

59. Id.

60. The term "genital-normalization" surgery throughout the text of this article refers to "nonconsensual" genital-normalization surgery, unless otherwise stated.

61. "The Court's insistence that the right to control one's body be protected from undue interference by others shows a developed principle of a right to bodily integrity that has evolved from the right to privacy." Joshua C. Albritton, Comment, Intersexed and Injured: How M.C. v. Aaronson Breaks Federal Ground in Protecting Intersex Children from Unnecessary Genital-Normalization Surgeries, 24 Tul. J.L. \& Sexuality 163, 173 (2015). The Supreme Court has found the Constitution to fundamentally protect procreational rights. Skinner v. Oklahoma, 316 U.S. 535, 541 (1942).

62. See Benjamin Sweeney, The Cobblestones of Good Intentions: Substantive Due Process and Infant Genital Normalizing Surgery, 13 Seattle J. Soc. Just. 153, 155 (2014).

63. In Germany, Christiane Völling was the first individual with intersex traits who won an award for damages in a lawsuit brought for genital-normalization surgery. In re Völling, (Regional Ct. Cologne, Ger.) (Case No. 25 O 179/07, Feb. 6, 2008), http://icj2.wpengine.com/wp-content /uploads/2008/02/In-re-Volling-Regional-Court-Cologne-Germany-English.pdf [https://perma.cc /V3VN-TXZQ]. Völling was a teenager when she underwent genital surgery. She was born with XX chromosomes with ambiguous genitals and was brought up as a boy. When Völling was fourteen years old, she required an appendectomy; at that time, surgeons discovered she had two ovaries. Völling had never been told that she had XX chromosomes, and when she turned eighteen years of age, she had an operation to remove her ovaries. Eventually, Völling identified as a female and, upon investigation, her medical records revealed the truth about her diagnosis. Id.; see also Christiane Völling: Hermaphrodite Wins Damage Claim over Removal of Reproductive Organs, ZwischengesCHLECHT.ORg (Aug. 12, 2009), http://zwischengeschlecht.org/pages/Hermaphrodite-wins-damage-claim [https://perma.cc/QAG6 -9YNB]. The surgeon was ordered to pay $€ 100,000$ in damages after a legal battle that began in 2007, thirty years after the removal of her reproductive organs. A second successful case in Germany, filed by Michaela Raab, was reported in 2015. Seelenlos, Nuremberg Hermaphrodite Lawsuit: Michaela "Micha" Raab Wins Damages and Compensation for Intersex Genital Mutilations!, STOP INTERSEX Genital Mutilations in Children's Clinics! (Dec. 17, 2015), http://stop.genitalmutilation.org/post /Nuremberg-Hermaphrodite-Lawsuit-Damages-and-Compensation-for-Intersex-Genital-Mutilations [https://perma.cc/9QMQ-XBAP]. Raab sought medical advice as she did not begin to menstruate or develop breasts by the time she was twenty years old. Physicians started her on female hormonal treatment and minimized the size of her clitoris. Raab learned years later that she had XY chromosomes, information that her physicians had withheld from her. Intersex Person Sues Clinic for Unnecessary Op, LoCAL (Feb. 27, 2015), http://www.thelocal.de/20150227/intersex-person-sues-doctors-for-unwanted -op [https://perma.cc/BB42-WEQV]. 
has established injury from genital-normalization surgery. However, in 2013, for the first time in the United States, a lawsuit was filed on behalf of an individual with intersex traits alleging a violation of constitutional rights because of genitalnormalization surgery. ${ }^{64}$ M.C. was born with ambiguous genitals and became a ward of the state of South Carolina. ${ }^{65}$ During this time, the South Carolina Department of Social Services held the authority to provide medical care for M.C. ${ }^{66}$

I28 Medical testing determined that M.C. had “ovotesticular DSD," which is characterized by the presence of both ovarian and testicular tissue. ${ }^{67}$ Although there was no medical need for surgery, one of the named defendants, a doctor employed by a state university hospital, decided on operations that would assign a female sex to M.C., while other named defendant employees of the same hospital concluded that M.C. could be raised as a boy or girl, and there was no way to make a determination at the time of future gender identity. ${ }^{68}$ At sixteen months of age, M.C.s surgeons performed "corrective" surgery to remove most of his ambiguous phallus, a testis, and testicular tissue on one gonad, and surgically encourage the appearance of female genitals. ${ }^{69}$ These procedures caused M.C. to be sterilized; without the surgeries he may have been capable of producing sperm.

I29 A Columbia, South Carolina, couple, the Crawfords, adopted M.C. after the surgery and raised M.C. as a girl according to the sex assignment. ${ }^{70}$ M.C. grew up to self-identify as a male. ${ }^{71}$ The Crawfords realized the constraints M.C. suffered through his genital-normalization surgery and joined with the Southern Poverty Law Center (SPLC) and interACT Advocates for Intersex Youth to file suit. They brought two complaints-one in federal court ${ }^{72}$ and one in state court ${ }^{73}$-against the doctors who participated in M.C.'s surgery and the South Carolina Department of Social Services and its employees.

\30 The federal complaint alleged that M.C.'s substantive due process rights ${ }^{74}$ of procreation, privacy, liberty, and bodily integrity were violated under the Fourteenth

64. This was a case of first impression in the United States, as M.C. is the first intersex plaintiff to assert constitutional claims in a federal court against a defendant for performing genitalnormalization surgery. Groundbreaking SPLC Lawsuit Accuses South Carolina, Doctors, and Hospitals of Performing Unnecessary Surgery on Infant, Southern Poverty LAW CTr. (May 13, 2013), https:// www.splcenter.org/news/2013/05/14/groundbreaking-splc-lawsuit-accuses-south-carolina-doctors -and-hospitals-unnecessary [https://perma.cc/4VR2-U96N].

65. Complaint at 11-12, M.C. v. Aaronson, No. 2:13-cv-01303 (D.S.C. May 14, 2013), 2013 WL 1961775.

66. Id. at 11 .

67. Id. at 12 .

68. Id. at $13-14$.

69. Id. at 15.

70. The Crawfords had hoped to prevent the unnecessary surgery once they saw M.C.'s profile on the State of South Carolina's child adoption website, but it had already been completed. Id. at 19.

71. Id.

72. Id. at 1 .

73. Complaint, M.C. ex rel. Crawford v. Med. Univ. of S.C., No. 2013CP400 (S.C. May 14, 2013), https://www.splcenter.org/sites/default/files/d6_legacy_files/downloads/case/Crawford_State _Complaint_Filed.pdf [https://perma.cc/3CFU-P4MP].

74. The SCDSS employees consented to M.C.'s surgery because the child was a ward of the state. The substantive due process claim is dependent on a government actor providing consent. If M.C.'s biological parents agreed to the surgery before parental rights were terminated, then a Fourteenth Amendment claim would not have been a feasible legal strategy. The Fourteenth Amendment does not protect against unjust private actions. Sweeney, supra note 62, at 183 . 
Amendment as a result of unnecessary, merely cosmetic genital surgery. ${ }^{75}$ The complaint also asserted a violation of M.C.'s procedural due process rights under the Fourteenth Amendment by subjecting M.C. to this procedure without a predeprivation hearing to examine whether the procedure was in M.C.'s best interest. ${ }^{76}$ The case was accepted by the federal district court to go to trial, and the court acknowledged that M.C. sufficiently alleged both a violation of his substantive due process right to procreation $^{77}$ and his procedural due process right to a pre-deprivation hearing. ${ }^{78}$ The district court then rejected the defendants' motion to dismiss and rejected their defense of qualified immunity. ${ }^{79}$ Subsequently, the defendants interlocutorily appealed the rejection of this defense. In January 2015, the U.S. Court of Appeals for the Fourth Circuit reversed and remanded with instructions to dismiss the complaint. ${ }^{80}$ The Fourth Circuit found that M.C.'s asserted rights were not sufficiently clear at the time of the operation so as to give officials reasonable fair warning of their violation. ${ }^{81}$

I31 M.C.'s state complaint was filed against the Medical University of South Carolina (MUSC) and the Greenville Hospital System, alleging medical malpractice, ${ }^{82}$ and the South Carolina Department of Social Services (SCDSS), alleging gross negligence. ${ }^{83}$ The case against the Greenville Hospital System has been settled by the parties. ${ }^{84}$ While this disposition leaves the law unclear at this moment, and may indicate that litigation over such issues might be a difficult path for plaintiffs, there is still a pending lawsuit against MUSC and SCDSS. This case is likely to be litigated in spring 2017, and the results will be significant. "There is a growing community of intersex individuals seeking answers and apologies for the medical treatments they received as children," ${ }^{85}$ and litigation involving victims of intersex infant surgeries is likely to increase. ${ }^{86}$

\section{Annotated Bibliography}

Albritton, Joshua C. "Intersexed and Injured: How M.C. v. Aaronson Breaks Federal Ground in Protecting Intersex Children from Unnecessary GenitalNormalization Surgeries." Tulane Journal of Law \& Sexuality 24 (2015): 163-78. This student comment analyzes the factual and legal background of M.C. v. Aaronson and further explores how causes of action arise from genital-normalization surgeries. Medical malpractice considerations arise when physicians fail to inform parents that medical surgeries are not medically necessary. Constitutional issues are borne out of genital-normalization surgeries that result in irreversible damage to sexual

75. Complaint, supra note 65 , at 21.

76. $I d$. at $22-23$.

77. Id. at $9-10$.

78. Id. at $11-12$.

79. Order, M.C. v. Aaronson, No. 2:13-cv-01303 (D.S.C. Aug. 29, 2013), 2013 WL 11521881.

80. M.C. ex rel. Crawford v. Amrhein, 598 F. App'x 143, 148 (4th Cir. 2015).

81. Id. at 149 .

82. Complaint, supra note 73 , at $13-17$.

83. Id. at $17-18$.

84. Public Index Search for Case No. 2013CP4002877, Richland Cty.; 5th Jud. Cir. Pub. Index (2013), http://www6.rcgov.us/SCJDWEB/PublicIndex/(X(1)S(uwx3krpgqk4ksaaaiqkwnfvv)) /CaseDetails.aspx?County=40\&CourtAgency=40002\&Casenum=2013CP4002877\&CaseType=V.

85. Skylar Curtis, Reproductive Organs and Differences of Sex Development: The Constitutional Issues Created by the Surgical Treatment of Intersex Children, 42 McGeORGE L. REv. 841, 865-66 (2011).

86. GreenberG, supra note 2, at 107. 
function and reproductive ability. The author suggests that M.C. v. Aaronson opens the door for more conversation related to the protection of intersex individuals. Specifically, the author proposes that legal mechanisms should be put in place to protect intersex infants from genital-normalization surgeries performed by the state, as well as those consented to by their own parents.

Beh, Hazel Glenn, and Milton Diamond. "David Reimer's Legacy: Limiting Parental Discretion.” Cardozo Journal of Law \& Gender 12 (2005): 5-30.

Here, the authors examine whether a parent should have the authority to consent to infant genital-normalization surgeries. The article questions "whether parents and intersex infants share a community of interests sufficient to grant parental authority" (p.30), or if societal influences have transformed a socially necessary surgery into a medically necessary surgery grossly favoring the interest of the parents. The authors set the story of David Reimer (the subject of Dr. John Money's failed nurture versus nature study) as the backdrop of the article, a reminder that David's death should serve as a caveat to those involved with genital normalization. The authors argue that even a heightened informed consent model cannot justify a medically unnecessary surgery, premised only on concerns about social stigma and gender conformity.

Benson, Sara R. "Hacking the Gender Binary Myth: Recognizing Fundamental Rights for the Intersexed." Cardozo Journal of Law \& Gender 12 (2005): 31-63. This article injects constitutional law considerations into the conversation about intersexed individuals and the informed consent doctrine. Establishing the modern informed consent doctrine, Benson states the general legal rule: a parent or guardian can legally consent on behalf of a minor child to intersex surgery so long as the surgery is in the child's best interest. Benson proposes a new informed consent standard, one that imports constitutional principles, specifically, the fundamental right to bodily integrity, personality, sexuality, and gender identity. According to Benson, the inclusion of the fundamental rights would force the courts to balance the constitutional right of the child to choose his or her own future with the right of the parent to control the upbringing of the child.

Ford, Kishka-Kamari. "'First, Do No Harm'-The Fiction of Legal Parental Consent to Genital-Normalizing Surgery on Intersexed Infants.” Yale Law \& Policy Review 19 (2001): 469-88.

This student note argues that parents cannot legally consent to their child's genital-normalization surgery. Ford questions whether the emergency exception to the informed consent doctrine can be applied to genital-normalization surgeries and if the surgeries can be fairly characterized as nonexperimental. Answering both questions in the negative, Ford labels parental informed consent to this type of surgery a fiction, warning doctors who have performed the surgery that legal informed consent has not been established. Ford concludes her piece by stating, "a moratorium should be declared on the use of defenseless infants as the experimental subjects of genital normalizing surgery" (p.488).

Fox, Marie, and Michael Thomson. "Cutting It: Surgical Interventions and the Sexing of Children." Cardozo Journal of Law \& Gender 12 (2005): 81-97.

This article examines the proffered justifications for male circumcision and compares them to those held out in support of intersex surgeries. The authors criticize scholars who have dismissed the relevancy of drawing parallels between the two types of infant surgeries. Enforcing the connection, the authors offer that at the very core, both procedures are derived from "the involvement of health 
professionals in surgical interventions which remove healthy tissue from the body of a child who is unable to provide consent" (p.84). The authors suggest that the acceptance of both procedures involved a certain combination of medical practice, class, and gender, but that male circumcision may have paved the way for intersex surgeries.

Greenberg, Julie A. Intersexuality and the Law: Why Sex Matters. New York: New York University Press, 2012.

The author, the leading legal scholar on intersex issues, details the surgical interventions performed on intersex infants to conform genitalia to the medically created definition of "normal." She examines the unique challenges the intersex community faces in securing legal protection against these unnecessary cosmetic genital surgeries and explores how the law can operate to safeguard the rights of intersex individuals. The author considers potential ways that the intersex movement might use legal arguments and strategies to further its goals.

Huddleston, Ashley. "Intersex Children in Foster Care: Can the Government Elect Sex Assignment Surgery?” Journal of Law \& Policy 22 (2014): 957-1004.

This student note draws from the facts of M.C. v. Aaronson and asks whether government officials have the ability to consent to sex assignment surgery on behalf of an intersex child in the custody of the state. Huddleston argues that, for the purposes of state foster care procedures, sex assignment surgery is neither a medical emergency nor is it routine. Huddleston contends that sex assignment surgery must then be classified as extraordinary, a classification under certain state laws for procedures that require judicial approval. Based on this analysis, Huddleston concludes that government officials must seek judicial approval prior to electing sex assignment surgery on behalf of an intersex child in their custody.

Martin, Patricia L. "Moving Toward an International Standard in Informed Consent: The Impact of Intersexuality and the Internet on the Standard of Care." Duke Journal of Gender Law \& Policy 9 (2002): 135-69.

This article addresses three questions: (1) What is the appropriate and evolving standard of care for the intersexed individual? (2) What constitutes informed consent when physicians treat the intersexed individual and his or her family? (3) What other torts might concern the medical professional when treating an intersexed individual? Analysis of these issues leads the author to call for new treatment protocols, ones that specifically incorporate the opportunity to explore the needs of the intersex community, to evaluate current treatment standards, and to investigate how other countries are tackling this issue-or, as Martin calls it, a "time out."

Sweeney, Benjamin. "The Cobblestones of Good Intentions: Substantive Due Process and Infant Genital Normalizing Surgery." Seattle Journal for Social Justice 13 (2014): 153-88.

The foundation of this student piece is derived from M.C. v. Aaronson and asks whether surgical sex assignment of intersex children violates their substantive due process rights. The author explores the application of the following due process rights that have been previously recognized by the courts: the right to privacy, liberty, and preservation of bodily integrity. While the author acknowledges the viability of a substantive due process claim in a case like M.C. v. Aaronson, where the child was a ward of the state, he recognizes the limitations of the substantive due process claim in a case void of the state actor requirement and with parental consent. 
Tamar-Mattis, Anne. "Sterilization and Minors with Intersex Conditions in

California Law." California Law Review Circuit 3 (2012): 126-35.

This article analyzes how a California court might rule on a motion to authorize an intersex surgery that would result in the sterilization of the intersex child. The author analogizes the sterilization of intersex children with the sterilization of a developmentally disabled individual, a situation already addressed in the California Probate Code. Expanding this framework to intersex infants/children, the author states that this scheme would allow for judicial intervention, including court-appointed counsel for the intersex child. According to the author, since California has already recognized the need to protect minors and those who cannot consent when reproductive freedom is at stake, extending the same rights to intersex minors is a natural, and necessary, next step.

White, Ryan L. "Preferred Private Parts: Importing Intersex Autonomy for M.C. v. Aaronson." Fordham International Law Journal 37 (2014): 777-821.

This student note compares four international sex assignment cases to the seminal lawsuit in the United States, M.C. v. Aaronson. The author applies the legal rationales from decisions in Colombia and Germany to M.C. v. Aaronson to argue that genital-normalizing surgery violates an individual's fundamental right to liberty. Specifically, the author argues that the timing of the surgery and the resulting deprivation of the individual's right to self-determination render the genital-normalizing surgery unconstitutional. The author concludes by suggesting that the protection of fundamental rights for intersex individuals in the United States is near.

\section{Confines of a Binary System}

I32 While the term "gender" refers to social and cultural differences, and the term "sex" refers to an individual's biological sex, ${ }^{87}$ the difference between the meaning of the terms "sex" and "gender" goes frequently unnoticed in society and in official documents. In the annotations of this bibliography, I have used whichever term the author uses, "gender" or "sex," as the two terms are often used interchangeably in the legal realm. ${ }^{88}$

\33 Over time our society has become more accepting of "gender" as a spectrum, where male and female lines blur, but the same cannot be said about "sex." In 2014, Facebook initiated the use of many possible terms for people to describe their gender; some of these terms are intersex, agender, bigender, pangender, genderqueer, and androgyne, among others. ${ }^{89}$ In the same year, the dating website OKCupid added new gender options for those individuals who do not fall in the

87. Am. Psychol. Ass'n, Definitions Related to Sexual Orientation and Gender Diversity in APA Documents, https://www.apa.org/pi/lgbt/resources/sexuality-definitions.pdf [https://perma.cc /DLZ8-4EJ2]. Only in the past few decades have medical and mental health specialists closely examined the differences between sex and gender. Charlene L. Muehlenhard \& Zoe D. Peterson, Distinguishing Between Sex and Gender: History, Current Conceptualizations, and Implications, 64 SEX Roles 791 (2011).

88. Julie A. Greenberg, What Do Scalia and Thomas Really Think About Sex? Title VII and Gender Nonconformity Discrimination: Protection for Transsexuals, Intersexuals, Gays and Lesbians, 24 T. JEFFERSON L. REv. 149, 150 (2002).

89. Tom McKay, Facebook Just Created 50 New Gender Options for Users to Choose From, Mic.com (Feb. 13, 2014), https://mic.com/articles/82241/facebook-just-created-50-new-gender -options-for-users-to-choose-from\#.S1aVH0Dqy [https://perma.cc/6LWM-E48W]. 
binary; these now include agender, adrogynous, bigender, cis man, cis woman, genderfluid, genderqueer, hijra, intersex, nonbinary, other, pangender, transfeminine, transgender, transmasculine, transsexual, trans man, trans woman, and twospirit. ${ }^{90}$ Previously, OKCupid allowed users to select only from male, female, straight, bisexual, and gay.

I34 The adoption and use of nonbinary gender classifications by academic institutions is another sign of the social evolution. The use of preferred personal pronouns in universities and colleges in the United States is gaining traction, ${ }^{91}$ and many provide these preferences to faculty in class rosters. Some of these personal pronoun preferences that expand the he/she binary include "xe," "xyr," and "xem,", among many other options.

\35 Although there has been real progress in challenging traditional gender stereotypes and rigid gender norms, and accepting that gender is but a social construct, there is less acceptance that sex itself does not comply with rigid binaries. ${ }^{93}$ Our bodies are simply subject to biological variation, but somehow the binary perspective of two sexes-male and female-and the pathologizing of deviation from this norm is firmly rooted in our society. However, there is some evidence that the tide may be turning ever so slowly. In June 2016, a landmark ruling in Oregon held that an individual who did not identify as male or female is now legally considered nonbinary. ${ }^{94}$ This ruling in the Circuit Court of the State of Oregon, Multnomah County is believed to be the first nonbinary legal classification in the United States. ${ }^{95}$

\$36 Another sign of change can be seen in a decision filed in a 2015 federal discrimination lawsuit against the U.S. State Department on behalf of an individual with intersex traits, Dana Zzyym. ${ }^{96}$ Dana was denied a U.S. passport because Dana did not choose either male or female on a passport application form; no other gender categories are provided on the form, and Dana does not identify as male or

90. Curtis M. Wong, OKCupid Begins Rolling Out New Gender, Sexuality Options, HuffingtoN Post (Nov. 17, 2014), http://www.huffingtonpost.com/2014/11/17/okcupid-new-gender-options_n _6172434.html [https://perma.cc/RQ23-74S3].

91. Adam Tamburin, Colleges Trend Toward Gender-Neutral Pronouns, USA TodAy (Sept. 5, 2015), http://www.usatoday.com/story/news/nation/2015/09/05/colleges-trend-toward-gender-neutral -pronouns/71780214/ [https://perma.cc/2EW8-PH47?type=image].

92. The Need for a Gender-Neutral Pronoun, Gender Neutral Pronoun Blog, https://gender neutralpronoun.wordpress.com/ [https://perma.cc/4THB-M7ZL].

93. The same cannot be said in all cultures, some of which include intersex individuals in a "third gender" category. See infra annotations following II 41.

94. In re Sex Change of Jamie Shupe, Case No.: 16CV13991 (June 10, 2016), http://www .portlandmercury.com/images/blogimages/2016/06/15/1466024211-shupe_ruling.pdf.

95. Christopher Mele, Oregon Court Allows a Person to Choose Neither Sex, N.Y. Times (June 13, 2016), http://www.nytimes.com/2016/06/14/us/oregon-nonbinary-transgender-sex-gender.html. Oregonians currently cannot list a nonbinary classification on a driver's license, so state officials are now working on a process to remove that barrier. $I d$. A second person has changed sex classification from female to nonbinary in 2016. Mary Emily O’Hara, Californian Becomes Second US Citizen Granted "Non-Binary" Gender Status, NBC News (Sept. 26, 2016), http://www.nbcnews.com/feature /nbc-out/californian-becomes-second-us-citizen-granted-non-binary-gender-status-n 654611 [https://perma.cc/LF3W-M53U].

96. The complaint asserts that the U.S. State Department violates the Due Process and Equal Protection Clauses of the Fifth Amendment to the U.S. Constitution, as well as the federal Administrative Procedure Act. Complaint at 15, 17, 12, 14, Zzyym v. Kerry, No. 1:15-cv-2362 (D. Colo. Oct. 25, 2015), 2015 WL 6449495. 
female. A federal judge pressed the State Department to issue a gender-neutral passport stating, "A lot of things are changing in our world." ${ }^{97}$ In November 2016, the court found that the administrative record did not provide evidence that the Department "followed a rational decisionmaking process in deciding to implement its binary-only gender passport policy." ${ }^{88}$ The court remanded the case to the U.S. State Department "to give it an opportunity either to shore up the record, if it can, or reconsider its policy." ${ }^{9}$

I37 Some scholars theorize that a third sex category would support individuals with intersex traits by denouncing the binary system. ${ }^{100}$ However, many intersex activists view these proposals to be outside the "primary" focus of their movement to end nonconsensual genital-normalization surgery, and that "until there is a prohibition on the practice ..., proposals for an alternative solution must take a step back." 101 The intersex community advocates that all children should receive a binary sex assignment dependent upon the medical condition discovered at birth; once the child develops a gender identity, the child may decide to have surgery or not, but would be able to consent to this intervention. ${ }^{102}$ The Council of Europe expressed concerns about recognition of third and blank classifications in a 2015 Issue Paper, stating that these may lead to "forced outings" and cause heightened strain on parents of children with intersex traits to select a sex for their child. The Issue Paper argues that "further reflection on non-binary legal identification is necessary." 103 Some scholars contend that the sex binary system itself validates and compels the continued practice of genital-normalization surgery. ${ }^{104}$

I38 Other scholars propose that we not only eliminate sex classifications that determine peoples' rights by opposing the binary system, but also via the eradication of government-required sex classification on official papers such as birth certificates and passports. ${ }^{105}$ Two of the most cited reasons given for sex classification for legal purposes, military combat and marriage, are no longer essential. The fact that one's sex must be noted on every official identifying paper illustrates how our society emphasizes the legal significance of this characteristic. Some activists state that dispensing with sex and gender classifications from

97. Federal Judge Urges US to Grant Gender Neutral Passport, Fox News (July 21, 2016), http:// www.foxnews.com/politics/2016/07/21/federal-judge-urges-us-to-grant-gender-neutral-passport .html.

98. Zzyym v. Kerry, No. 15-CV-02362-RBJ, 2016 WL 7324157 (D. Colo. Nov. 22, 2016), at 3.

99. Id.

100. Hofman, supra note 57 , at 19.

101. Hupf, supra note 49 , at 104.

102. Consortium on the Mgmt. of Disorders of Sex Dev., Clinical Guidelines for the Management of Disorders of Sex Development in Childhood 38 (2006), http://www.dsdguide lines.org/files/clinical.pdf [https://perma.cc/S69P-9Y93]. Intersex activists' recommendations to assign a gender to an intersex infant is often based on protecting intersex children and adults, likely due to their own experiences of ostracism and distress from sex nonconformity.

103. Council of Europe, Comm'r for Human Rights, Human Rights \& Intersex People, Issue PAPER 40 (Apr. 2015), https://wcd.coe.int/com.instranet.InstraServlet?command=com.instranet . CmdBlobGet $\&$ InstranetImage $=2933521 \&$ SecMode $=1 \&$ DocId $=2367288 \&$ Usage $=2 \quad[$ https: $/ /$ perma.cc /7KVQ-9U2N].

104. See Samantha S. Uslan, Note, What Parents Don't Know: Informed Consent, Marriage, and Genital-Normalizing Surgery on Intersex Children, 85 IND. L.J. 301, 304 (2010).

105. James McGrath, Are You a Boy or a Girl? Show Me Your REAL ID, 9 Nev. L.J. 368, 369-70 (2009). 
official documents, similarly to race and religion, is a long-term strategic goal for the movement. ${ }^{106}$

\39 Various countries have moved to recognize third gender designations, and progressive groups have welcomed the laws as a sign of success for intersex rights. In 2013, Germany became the first country in Europe to acknowledge a third gender designation: $\mathrm{X}$, for indeterminate or intersex. ${ }^{107}$ An infant with intersex traits will not be required to endure medical intervention when born with ambiguous sex characteristics. In that case, an infant will have an "X" marked on the birth certificate, rather than the rigid categories of $\mathrm{M}$ or $\mathrm{F}$. This step allows intersex children to decide their gender identity when they reach adulthood, rather than legally or surgically forcing a gender identity upon them without their consent. At the same time, the interior ministry declared that German passports would similarly allow a third designation, $\mathrm{X}$, for intersex citizens. ${ }^{108}$ The German third gender designation has angered some intersex-rights groups, which object to its stipulation that a child who is classified as neither female nor male will be noted in the register of births without such assignment. ${ }^{109}$ The law appears to "necessitate" exclusion from the binary classification, so it still leaves judgment to the medical world, not as an option for the parents. ${ }^{110}$

I40 Other countries issuing passports or national identity cards with an " $\mathrm{X}$," "other," or "E" (eunuch) ${ }^{111}$ marker for nonbinary categories include Australia, ${ }^{112}$

106. Morgan Carpenter, The Human Rights of Intersex People: Addressing Harmful Practices and Rhetoric of Change, Reproductive Health Matters, May 2016, at 74, 79.

107. Michelle Castillo, Germany to Allow Third Gender Designation on Birth Certificates, CBS News (Nov. 1, 2013), http://www.cbsnews.com/news/germany-to-allow-third-gender-designation-on -birth-certificates [https://perma.cc/NK7J-ZQS4]. However, the German government emphasizes that this "third blank box isn't an official third gender, or the 'other' box-so it doesn't actually mean that there are now three recognized genders in Germany. It's seen as a temporary solution for very specific intersex cases-the children are not expected to live their lives as Xs, but to make a decision to be male or female at a non-specified point in the future." Jacinta Nandi, Germany Got It Right by Offering a Third Gender Option on Birth Certificates, Guardian (Nov. 10, 2013), http://www.theguardian.com /commentisfree/2013/nov/10/germany-third-gender-birth-certificate [https://perma.cc/3Z44-3NPF]. Germany does not include sex as a category on its ID cards. Miriam Dalli, Male, Female or X: The New Gender Options on Identification Documents, Malta ToDay (Feb. 3, 2015), http://www.maltatoday.com .mt/news/national/49185/male_female_or_x_the_new_gender_options_on_identification_documents\# .WEB89lw0-nY [https://perma.cc/YZK7-2KXN].

108. Castillo, supra note 107.

109. Nandi, supra note 107.

110. Sham Package for Intersex: Leaving Sex Entry Open Is Not an Option, OII EuRope (Feb. 15, 2013), http://oiieurope.org/bluff-package-for-inter-leaving-sex-entry-open-is-not-an-option/ [https://perma.cc/54ST-TDCA].

111. Jennifer Rellis, Please Write "E" In This Box: Toward Self-Identification and Recognition of a Third Gender: Approaches in the United States and India, 14 MicH. J. GENDER \& L. 223, 233 (2008).

112. Christopher Zara, Intersex Australia: Third Gender Allowed on Personal Documents in Addition to Male and Female, InT'L Bus. Times (June 14, 2013), http://www.ibtimes.com/intersex -australia-third-gender-allowed-personal-documents-addition-male-female-1307843 [https://perma .cc/6VYU-9HS7]. 
Bangladesh, ${ }^{113}$ Colombia, ${ }^{114}$ Denmark, ${ }^{115}$ India, ${ }^{116}$ Malta, ${ }^{117}$ Nepal, ${ }^{118}$ New Zealand, ${ }^{119}$ and Pakistan. ${ }^{120}$ These are examples of jurisdictions using a tool other than the judiciary to recognize intersex or otherwise gender-variant individuals.

I41 Intersex activists' paramount goal and efforts are to see a moratorium on nonconsensual genital-normalization surgery, not to first champion a movement to reform the binary sex classification system. Banning nonconsensual genitalnormalization surgery would be a breakthrough in intersex rights, and, once this issue is resolved, we should see more focus on support for the termination of our preoccupation with the male/female sex binary.

\section{Annotated Bibliography}

Gruber, Natascha. "Ethics in Medicine: With a Special Focus on the Concepts of Sex and Gender in Intersex Management." Cardozo Journal of Law \& Gender 12 (2005): 117-25.

This article provides an outline of the author's research project for the Beatrice Bain Research Group on Gender at the University of California, Berkeley, entitled, "Open Sex-Undoing Gender." The project focuses on issues related to a multiple sex/gender model, and asks whether an alternative to the binary system could initiate new approaches to intersex treatment. Although the author is not "purposely opposed" to a multiple sex/gender model, she acknowledges that it raises collateral issues. She advocates instead for an increased focus on recognizing a broader range of sexual possibilities: "[R]ecogniz[ing] a broader range of sexual possibilities in general and for patients would subvert and replace heterosexist ideologies in current intersex management in the long run" (p.125).

Hofman, Darra L. Clark. "Male, Female, and Other: How Science, Medicine and Law Treat the Intersexed, and the Implications for Sex-Dependent Law." Tulane Journal of Law \& Sexuality 21 (2012): 1-21.

This article examines how certain legal rights related to fundamental aspects of life depend on the cultural and social views on gender and sex. Hofman criticizes the law's continued reliance on binary categories in spite of scientific advance-

113. Mohosinul Karim, Hijras Now a Separate Gender, DhakA TriB. (Jan. 26, 2014), http:// www.dhakatribune.com/bangladesh/2013/nov/11/hijras-now-separate-gender [https://perma.cc /E43R-3PLU].

114. Daniela Franco, Colombia, the Surprising Global Leader in Transgender Rights, TAKEPART (June 10, 2015), http://www.takepart.com/article/2015/06/10/colombia-surprising-global-leader -transgender-rights [https://perma.cc/BW42-VEKD].

115. Mitch Kellaway, Denmark Passes Groundbreaking Gender "Self-Determination" Law, AdvocAte (Sept. 3, 2014), http://www.advocate.com/politics/transgender/2014/09/03/denmark -passes-groundbreaking-gender-self-determination-law [https://perma.cc/G57Q-S85R].

116. India Recognizes Transgender Citizens as "Third Gender," RT.com (Apr. 15, 2014), https:// www.rt.com/news/india-court-third-gender-636/ [https://perma.cc/7AYM-T5ES].

117. Dalli, supra note 107.

118. Clarissa-Jan Lim, New “Third Gender" Option on Nepal Passports Finally Protects the Rights of LGBT Community, BustLE (Jan. 8, 2015), http://www.bustle.com/articles/57466-new-third -gender-option-on-nepal-passports-finally-protects-the-rights-of-lgbt-community [https://perma.cc /LX87-NLUL].

119. Information About Changing Sex/Gender Identity, [N.Z.] IDENTITY \& PAssPoRTs, https://www.passports.govt.nz/Transgender-applicants\#gender\%20identity [https://perma.cc/3QH7 -AZAW].

120. Rabail Baig, A First for Pakistan's Third Gender, FoneIgn Pol'y (Mar. 30, 2012), http:// foreignpolicy.com/2012/03/30/a-first-for-pakistans-third-gender/ [https://perma.cc/W5F2-JJQG]. 
ments that reveal the complexity of sex. Reliance on the binary results in the legal exclusion of those who do not fit neatly within the categories, such as intersexed individuals. Hofman explores a number of possible solutions to this issue, but maintains that "the best solution would be to eliminate sex as a category that determines peoples' rights” (p.19).

Knouse, Jessica. "Intersexuality and the Social Construction of Anatomical Sex." Cardozo Journal of Law \& Gender 12 (2005): 135-54.

The author first identifies three major areas of law that depend on sex-based distinctions: (1) official documentation, such as passports, birth certificates, and driver's licenses; (2) marriage rights; and (3) protection from discrimination. The legal definition of sex as applied within these areas of law prescribes a male/ female binary. According to Knouse, this is just one example of society's attempts to eradicate biological diversity. Another example is the medical treatment of intersex individuals and, in particular, genital-normalization surgeries. Knouse proposes a complete eradication of sex assignment, which she argues will enable biological diversity and liberate individuals from repressive categorization.

McGrath, James. "Are You a Boy or a Girl? Show Me Your REAL ID.” Nevada Law Journal 9 (2009): 368-406.

The REAL ID Act of 2005 requires states to adhere to federally mandated requirements in the issuance of all state identification cards and driver's licenses. One of the minimum requirements prescribed by the statute is an identification of the individual's gender. In this article, McGrath criticizes the gender identification requirement for two main reasons: (1) the statutory construction of this requirement bars any state from attempting to eliminate the gender identifier in an effort to protect its gender-variant citizens and reduce complications; and (2) gender is not an accurate method of verifying a person's identity. Further, McGrath argues that requiring a gender identification enforces the gender binary and may pressure parents of intersex individuals to consent to unnecessary gender assignment surgeries. Finally, McGrath argues that the gender identification requirement should be considered discriminatory against particular sexual minorities.

Reilly, Elizabeth. "Radical Tweak-Relocating the Power to Assign Sex: From Enforcer of Differentiation to Facilitator of Inclusiveness: Revising the Response to Intersexuality." Cardozo Journal of Law \& Gender 12 (2005): 297-335.

This author's proposal is crystal clear: "[W]e must cease using the Birth Certificate to assign sex to a child" (p.308). Reilly illuminates three distinct reasons why assigning sex at birth is problematic: (1) an individual's sexual identity is not determinable at birth, nor is it unchanging; (2) the medium on which the assignment is made-an official legal document-has permanent legal implications; and (3) sex is assigned by medical professionals, further enforcing the fallacy that biological sex is easily determinable. Reilly's proposal calls for complete removal of the sex category from the birth certificate, stating that data related to sex identity will be reported only for medical and health purposes in a specific vital statistics section that accompanies all birth certificates. Under this model, the formalization of sex identity will be self-reported on other documents, such as passports and driver's licenses.

Vanderhorst, Blaise. "Whither Lies the Self: Intersex and Transgender Individuals and a Proposal for Brain-Based Legal Sex." Harvard Law \& Policy Review 9 (2015): 241-74.

This article explores how the intersex and transgender movements have increased the recognition of sexual indeterminacy and shattered the assumptions about sex 
and gender that the entire U.S. legal system is built on. The failure to recognize sexual diversity in the law has created a legal uncertainty for transgender and intersex individuals, and has further marginalized both groups. This author argues that "[g]ender is truly between the ears, not between the legs" (p.245) and endorses gender self-identity as the sole criterion for the determination of legal sex. Calling for the elimination of all sex assignment, and sex-assignment surgeries in particular, the author acknowledges the challenges of implementing such radical changes, yet maintains that gender self-identification is the "only rational and humane criteria for legal sex" (p.246).

\section{Discrimination}

\section{Discrimination Generally}

I42 Individuals with intersex traits frequently find themselves facing discrimination if their intersexuality becomes known or if they are recognized as gender nonconformists. Laws against discrimination do not generally address discrimination against intersexual individuals, leaving them unprotected in an array of environments, such as healthcare, education, public services, employment, and sports. ${ }^{121}$ The U.N. Human Rights Office of the High Commissioner urges that we "prohibit discrimination on the basis of intersex traits, characteristics or status ... and address such discrimination through relevant anti-discrimination initiatives." 122

\section{Annotated Bibliography}

Antonopoulos, Nicole. "The Unconstitutionality of the Current Housing Arrangements for Intersex Prisoners." Hastings Constitutional Law Quarterly 42 (2015): 415-42.

This student note discusses the ways that prison officials house and treat intersex prisoners. Potential constitutional challenges and equal protection claims are analyzed in light of housing classifications. The author suggests that intersex discrimination is a form of sex discrimination; thus, a classification differentiating intersex persons from non-intersex persons is one that merits heightened scrutiny to determine whether there is a violation of the Equal Protection Clause. The author examines various prison system approaches in an attempt to find a humane solution for housing intersex individuals.

Berghausen, Mark E. "Intersex Employment Discrimination: Title VII and Anatomical Sex Nonconformity." Northwestern University Law Review 105 (2011): 1281-315.

This student comment sets out to answer the general question of whether an intersex individual is protected from sex discrimination under Title VII or by state antidiscrimination laws that prohibit discrimination based on sex. After providing a brief background of what he identifies as sexual minorities, the author discusses the limited relevant case law, most of which pertains to transsexual individuals. The author advances the argument that the most sensible

121. See infra "Foreign Approaches to Intersex Rights-Discrimination," III 73-78, for a discussion of foreign jurisdictions that address discrimination.

122. U.N. Office of the High Comm'r for Human Rights, Free \& Equal Campaign Fact Sheet: Intersex, https://unfe.org/system/unfe-65-Intersex_Factsheet_ENGLISH.pdf [https://perma .cc/XS84-HS73]. 
interpretation of Title VII protects an intersex individual and argues for a cause of action for discrimination based on anatomical nonconformity.

Ezie, Chinyere. "Deconstructing the Body: Transgender and Intersex Identities and Sex Discrimination-The Need for Strict Scrutiny." Columbia Journal of Gender \& Law 20 (2011): 141-99.

Highlighting the parallels between race discrimination and sex discrimination, this author proposes that sex categories be recognized as suspect classifications for the purposes of the equal protection doctrine. Ezie acknowledges that the idea is not novel, but contends that the approach-"asserting that the constructed character of sex, and its mutability, provide an independent basis for finding sex classifications suspect" (p.179) - is new and is not without support. Recognition of sex as a social construction for the purposes of an equal protection sex discrimination analysis, Ezie argues, will foster a greater understanding of gender discrimination in general.

Gelfman, Ilana. "Because of Intersex: Intersexuality, Title VII, and the Reality of Discrimination 'Because of ... [Perceived] Sex." New York University Review of Law \& Social Change 34 (2010): 55-122.

This author criticizes previous scholarly work that suggests adding a third category specifically for intersex individuals, stating that instituting such an idea would perpetuate gender stereotyping and further reinforce the notion that sex and gender categories should and do exist. As an alternative, Gelfman proposes a model that interprets Title VII protections to extend to an individual's "perceived sex." Perceived sex is defined in the article as "the gender assignment applied by the discriminating party to the employee" and "the gender assignment applied by the discriminating party to the gender expressions of the employee" (p.111). According to Gelfman, this interpretation is flexible and sensitive to the social reality of discrimination, which is why it is appropriate in the context of sex and gender.

Greenberg, Julie A. "Health Care Issues Affecting People with an Intersex Condition or DSD: Sex or Disability Discrimination?” Loyola of Los Angeles Law Review 45 (2012): 849-907.

Greenberg chronicles the historical and current medical treatment of intersex individuals and the unique healthcare issues confronting the intersex community. Greenberg focuses on the movement's primary goal to stop certain medical procedures from being performed on infants with DSD. Now that courts have recognized statutory protections against sex discrimination based on sex and gender stereotypes, Greenberg argues that a similar framework could be applied to bar the medical procedures. Greenberg writes, "If physicians and hospitals recommend these procedures because they decide that a child is not sufficiently masculine or feminine, they are arguably engaging in a form of sex discrimination" (p.896). Greenberg goes beyond the sex discrimination analysis by exploring whether current medical procedures performed on infants with DSD could also be considered a form of disability discrimination.

Greenberg, Julie A. "What Do Scalia and Thomas Really Think About Sex? Title VII and Gender Nonconformity Discrimination: Protection for Transsexuals, Intersexuals, Gays and Lesbians." Thomas Jefferson Law Review 24 (2002): $149-59$.

This article tracks the early Supreme Court decisions that first opened the door for the potential inclusion of sex and gender nonconformists under Title VII. 
Greenberg reveals that while most legislative acts use the word "sex," courts, legislators, and others replace the word "sex" with "gender." Even though the two terms are understood to be different, in the legal realm, "sex" and "gender" are used interchangeably. The failure to distinguish between the two, and to further acknowledge the existence of other individuals along a sex and gender spectrum, reflects the law's failure to adequately protect the sex and gender nonconformists. Along with the terminology issues, Greenberg states that most of the early case law was entirely undeveloped. In her conclusion, she urges scholars to encourage the courts to adopt a coherent theory of sexual harassment law that would protect all sexual minorities.

Menon, Yamuna. "The Intersex Community and the Americans with Disabilities Act." Connecticut Law Review 43 (2011): 1221-51.

This student note examines whether the Americans with Disabilities Act, particularly in light of recent amendments to the statute, provides an intersex individual with legal protection against discrimination. Menon highlights a section of the statute that excludes certain categories of individuals from its scope of protection, including individuals who identify as gay, lesbian, bisexual, or transgender. Menon argues that absent any express reference to the intersex community, this section opens the door for the intersex, provided the individual is able to meet the other statutory requirements. Whether the ADA is an ideal avenue for the intersex community to pursue legal protection, Menon writes, remains a critical question.

\section{Discrimination in Sports}

I43 Female athletes with intersex traits face many difficulties. They may have their sex disputed and find themselves excluded from competitions because of intersex traits, and many have been disgraced, disqualified, or forced to give back medals once their intersexuality became known. ${ }^{123}$ Females with body shapes that are more male-like or who display extreme speed or strength may have their sex called into question; it may be conjectured that the athlete possesses a distinct edge in a competition as a result of sex characteristics. It is possible in some instances that the athlete is intersex.

I44 Sex verification was initiated at the Olympics in 1968 with confirmation by physical examination; verification was later made using chromosome testing. This issue presented many problems for intersex athletes, as there are females who possess XY chromosomes (such as individuals with CAIS or PAIS) and males who possess XX chromosomes. ${ }^{124}$ Additionally, there are genes on chromosomes other than the X or Y that also affect sex development. Simply determining whether an athlete has XX or XY or some other variation will not determine definitively the individual's sex.

123. For example, Santhi Soundarajan, an Indian athlete who competed in the 800-meter race at the 2006 Asian Games, was forced to return her silver medal when she did not pass a sex verification test because she had androgen insensitivity syndrome. Other athletes' sex is questioned after death, such as happened to Stanisława Walasiewicz. Daniel Gandert et al., The Intersection of Women's Olympic Sport and Intersex Athletes: A Long and Winding Road, 46 IND. L. Rev. 387, 395-96 (2013).

124. This condition occurs when a gene of the $\mathrm{Y}$ chromosome resides on an $\mathrm{X}$ chromosome, which results in the $\mathrm{X}$ chromosome operating more like a Y chromosome. 
I45 These problems with chromosomal sex verification became apparent to the International Olympic Committee (IOC) in 1996, when they confronted difficult decisions with the results of sex testing. Seven of the eight women who were found to have male chromosomes had androgen insensitivity syndrome, ${ }^{125}$ and, thus, were unable to use the testosterone they made. It is worth remembering that most of us know whether we are men or women even though we have no idea what our "sex chromosomes" are. Gender identity is about who you know yourself to be, not about how your sex chromosomes look on a microscope slide. Doctors look at the "sex chromosomes" of people with DSD as part of coming up with a diagnosis, but they do not treat the "sex chromosomes" alone as a simple answer to anything. Our "sex chromosomes" are just part of the picture of who we are.

II46 Therefore, in 1999, since it was impossible to identify an athlete as completely male or female, the IOC eliminated "compulsory" sex verification. However, the IOC and the International Association of Athletics Federations (IAAF) reserved the right to test an athlete's chromosomes if uncertainty about her sex emerged and to require a hormonal test, a gynecological exam, and a psychological assessment.

II47 The IAAF, in 2011, instituted testing for hyperandrogenism ${ }^{126}$ in women athletes, due in large part to the Caster Semenya controversy. ${ }^{127}$ Testing is done when there are reasonable grounds for believing that a woman has the condition. A female athlete who possesses testosterone levels within the male range is prohibited from competition, unless either she is insensitive to testosterone or she decreases her testosterone.

I48 Similarly, IOC officials instituted testosterone level testing for the 2012 Olympic Games. The testing is not used for "all" athletes in women's competitions; this testing is done only when requested by the chief medical officer of a national Olympic committee or by a member of the IOC's medical commission when an individual's sex identification is called into question. Female athletes are barred from women's events if testing shows testosterone levels in the normal range for males. ${ }^{128}$ Those athletes with CAIS are permitted to participate in the games.

125. J.C. Reeser, Gender Identity and Sport: Is the Playing Field Level?, 39 BRIT. J. SporTs Med. 695, 696 (2005).

126. Hyperandrogenism is a condition in which the body produces higher than normal levels of hormones called androgens, particularly testosterone. Joanna Marchant, Women with High Male Hormone Levels Face Sport Ban, NATURE (Apr. 14, 2011), http://www.nature.com/news/2011/110414 /full/news.2011.237.html.

127. Caster Semenya is a South African runner. She won gold at the World Championships in 2009 in the women's 800-meter race. Due to her appearance, she was subjected to gender verification testing by the International Association of Athletics Federations (IAAF). The results were not released, but unconfirmed reports claim that although physically appearing to be a woman, she has internal testicles and does not have a uterus or ovaries. Ariel Levy, Either/Or, New Yorker, Nov. 30, 2009 , at $46,48-49$. Semenya was suspended for nearly a year by the IAFF before being cleared to run in 2010. Runner Wins Three Titles in Four Hours, N.Y. TimEs, Apr. 17, 2016, at SP6.

128. This IOC policy is discriminatory on its face because there are no guidelines on what is an acceptable level of testosterone for men competing in men's events. For example, the intersex condition Diplo (XYY) causes higher levels of testosterone than in nonintersex men, yet the IOC policy does not ban men with Diplo from events, and these men could also be seen as having an unfair physical advantage. Kathryn E. Henne, Testing for Athlete Citizenship: Regulating Dope and Sex IN SPORT 91 (2015). 
I49 Scholars have criticized hyperandrogenism testing in female athletes, stating that it is significantly flawed. ${ }^{129}$ There are privacy concerns the athletes will face. The testing means that many women athletes will face mandatory, but unnecessary, hormonal therapy, or have undescended testes surgically removed, if they want to continue to participate in competition. It is likely that "sex policing" will become more rampant. Recommendations have been made that athletes be allowed to participate in accordance with their legal $\operatorname{sex}^{130}$ or their gender identity. ${ }^{131}$

I50 In 2014, the British Medical Journal reported on a study of four young female athletes with 5-ARD who had gonadectomy and partial clitoridectomy procedures to participate in athletics after testing showed elevated androgen levels. ${ }^{132}$ The study maintains that this invasive and irreversible medical intervention was not medically necessary and undermines ethical care. All four athletes reside in developing countries where they may likely have difficulty with receiving lifetime hormone replacement therapy. The OIC and IAAF testosteronebased eligibility policies that mandate intervention conflict with the medical approach to hyperandrogenism, which considers the athlete's health, symptoms, and fertility goal.

I51 In July 2015, the International Court of Arbitration of Sport, the ultimate arbiter for conflict in sports, ruled that the IAAF's policy regarding natural testosterone is not supported by current scientific research. ${ }^{133}$ The court acknowledged that while natural testosterone may impact competitive advantage, exactly what that impact is, and how significant it is, is unclear at this time. The court declared that

while the evidence indicates that higher levels of naturally occurring testosterone may increase athletic performance, [the court] is not satisfied that the degree of that advantage is more significant than the advantage derived from the numerous other variables which the parties acknowledge also affect female athletic performance: for example, nutrition, access to specialist training facilities and coaching, and other genetic and biological variations. ${ }^{134}$

I52 Thus, the court found that mandating medical intervention for participation in sports was indefensibly discriminatory and suspended the IAAF's testosterone policy. The court provided the IAAF time to substantiate the claim that naturally high testosterone in females is equivalent to men's advantage in sports. If such proof does not materialize by July 2017, the testosterone policy will be declared void. ${ }^{135}$

129. See generally Karkazis et al., supra note 29, at 3.

130. Hida Viloria, Article: Hida Speaks About Her Involvement with the IOC in the Global Herald, HidaViloria (Apr. 11, 2011) http://hidaviloria.com/hida-speaks-about-here-involvement -with-the-ioc-in-the-global-herald/.

131. Erin Buzuvis, Hormone Check: Critique of Olympic Rules on Sex and Gender, 31 WIs. J.L. GENDER \& SOC'Y 29, 50 (2016).

132. Rebecca Jordan-Young et al., Sex, Health, and Athletes, 348 BMJ 20 (May 10, 2014).

133. Chand v. Athletics Fed'n of India (AFI), CAS 2014/A/3759, http://www.tas-cas.org/file admin/user_upload/AWARD_3759_FINAL__REDACTED_FOR_PUBLICATION_.pdf. [https:// perma.cc/EHM7-7L3E]; see also Ruth Padawer, Too Fast to Be Female, N.Y. Times (MAG.), July 3, 2016, at MM32.

134. Chand v. Athletics Fed'n of India (AFI), CAS 2014/A/3759.

135. Id. 
I53 Although the IOC relied upon the same science in its testosterone policy, it did not immediately suspend its policy, as the IAFF was compelled to do. In February 2016, the IOC did agree that it would not police women's natural testosterone levels until the controversy is settled. ${ }^{136}$ The IOC encouraged the IAAF to substantiate its claim before the policy could be declared void, so that the IOC could reinstitute their policy. ${ }^{137}$

\section{Annotated Bibliography}

Adair, Jessica L. "In a League of Their Own: The Case for Intersex Athletes." Sports Lawyers Journal 18 (2011): 121-51.

This article examines the legal remedies available to intersex athletes who are excluded from competition based on the intersex condition. As the author points out, as a preliminary matter, not all student athletes are protected equally under the law, which provides a significant hurdle for intersex individuals who have been discriminated against. Nevertheless, the article explores the potential legal causes of action, including equal protection and due process claims, as well as federal and state civil rights protections. Adair is not optimistic that a court will produce a favorable outcome for intersex individuals, but is hopeful that the discrimination of intersex individuals will be recognized by the judicial system in the future.

Gandert, Daniel, et al. “The Intersection of Women's Olympic Sport and Intersex Athletes: A Long and Winding Road." Indiana Law Review 46 (2013): 387-423. The authors use the personal narratives of multiple Olympic athletes who have been stigmatized following compulsory sex testing to illustrate the many issues associated with defining sex and gender in the realm of competitive sports. This article examines the history of sex testing in athletic competitions and the existing policies in Olympic sports. As the authors point out, regulations as applied to intersex athletes are particularly challenging due to the diverse nature of intersex conditions. The authors caution against future regulations that would be discriminatory in nature, such as the initiation of testing based on an athlete's appearance and any regulation that would unintentionally adopt or reinforce traditional sex stereotypes.

Glazer, Samantha. "Sporting Chance: Litigating Sexism Out of the Olympic Intersex Policy." Journal of Law \& Policy 20 (2012): 545-80.

In this student note, Glazer criticizes the traditional justifications for sex-testing Olympic athletes - the existence of the sex binary and the notion that fairness in sport requires separation of sexes-and argues that they "reflect a flawed understanding of sex and competitive advantage" (p.546). Glazer argues that sex-testing Olympic athletes for hyperandrogenism predominantly discriminates against women. Specifically, any policy requiring only female athletes to undergo sex testing for hyperandrogenism is facially discriminatory because it fails to address the acceptable level of androgen for male athletes. Glazer concludes that a discrimination lawsuit challenging the hyperandrogenism policy may be an effective avenue for female athletes to pursue.

136. Padawer, supra note 133.

137. Id. 
Karkazis, Katrina, et al. "Out of Bounds? A Critique of the New Policies on Hyperandrogenism in Elite Female Athletes," American Journal of Bioethics 12 (June 2012): 3-16.

This article examines the IOC's and IAFF's policies on hyperandrogenism. Karkazis and her colleagues question the legitimacy of these policies on three grounds. First, the underlying scientific assumption that atypically high levels of testosterone in females creates an unfair advantage is notably flawed. "[T] here is no scientific evidence showing that successful athletes have higher testosterone levels than less successful athletes" (p.8). Second, the policymaking process was flawed because the IOC and IAFF relied mainly on the expertise of those individuals connected to the questionable policies of the prior two decades. Third, the policies raise unsettling concerns about the potential to achieve fairness for female athletes, given the documented harms that female athletes have faced with evaluation and sex testing. It is unlikely that these policies will protect against breaches of privacy and confidentiality due to inconsistencies and suspension when undergoing evaluation. The authors believe that true consideration of fairness would promote a strategy that permits all legally recognized females to compete with other females, regardless of hormonal levels, as long as the hormones are naturally produced. The author urges that the IOC and IAFF policies be rescinded.

Zaccone, Laura A. "Policing the Policing of Intersex Bodies: Softening the Lines in Title IX Athletic Programs.” Brooklyn Law Review 76 (2010): 385-438.

This student note questions the place of intersex under Title IX, examining the statute's prohibition against sex discrimination specifically in the context of athletics. Zaccone notes the complexity of identifying biological distinctions within athletics, highlighting as a preliminary matter that one standard is not appropriate for all sports. Further, she argues that even sex-based differences, including those rooted in biology, are influenced by social and cultural judgments. Relying on the courts' history of interpreting Title IX as analogous to Title VII, Zaccone hypothesizes that recent case law prohibiting discrimination under Title VII against a transgender employee for failure to conform to the employer's gender expectations should open the door for intersex protection under Title IX. Under this theory, she argues that a student's self-identified gender should determine eligibility in Title IX athletics.

\section{Human Rights}

I54 Numerous local, national, and international human rights institutions; health institutions; national ethics bodies; and civil society organizations have been closely scrutinizing medical practices and discrimination faced by individuals with intersex traits. Generally, these organizations advocate for an end to nonconsensual genital "normalizing" interventions, viewing them as human rights abuses. ${ }^{138}$ Research in the field of human rights acknowledges an increasing consensus that there is a wide array of biological variation in the human

138. Many of these organizations have published investigations and reports on the human rights of intersex people. For example, the Human Rights Commission of San Francisco published one of the first human rights reports on the treatment of intersex individuals. CiTY \& CTY. OF S.F. Human Rts. Comm’n, A Human Rights Investigation into the Medical "Normalization” of Intersex People 17 (Apr. 2005) (concluding that genital-normalization surgeries performed without an individual's informed consent are inherent human rights violations). 
body, even if some of these are uncommon. ${ }^{139}$ Because their bodies are viewed as different, children and adults with intersex traits are often stigmatized and subjected to multiple human rights violations. In addition to discrimination and unequal treatment, these areas of concern include infringement of the right to health and physical integrity, the right to be free from torture and ill-treatment, ${ }^{140}$ and the right to procreate. ${ }^{141}$

I55 In 2013, the U.N. Special Rapporteur on Torture and Other Cruel, Inhuman or Degrading Treatment or Punishment, Juan Mendez, reported that genitalnormalization surgery was an abuse in medical care that crosses a threshold of mistreatment commensurate with torture or cruel, inhuman, or degrading treatment or punishment, and disguised as forms of reparative therapies. ${ }^{142}$ The report calls for all states to "repeal any law allowing intrusive and irreversible treatments, including forced genital-normalizing surgery ... when enforced or administered without the free and informed consent of the person concerned."143

I56 The World Health Organization (WHO) joined with other U.N. organizations in 2014 to condemn the forced sterilization of persons with intersex traits, stating that "if possible, irreversible invasive medical interventions should be postponed until a child is sufficiently mature to make an informed decision, so that they can participate in decision-making and give full, free and informed consent." ${ }^{144}$

I57 The U.N. Office of the High Commissioner for Human Rights (OHCHR), in 2015 recognized genital-normalization surgery as an irreversible, unnecessary intervention to enforce the sex binary, which can result in "severe, long-term physical and psychological suffering." 145

I58 During 2015, the Council of Europe, ${ }^{146}$ the European Union Agency for Fundamental Rights, ${ }^{147}$ and the Inter-American Commission on Human Rights ${ }^{148}$

139. Pediatric Gender Assignment: A Critical Reappraisal 155-56 (Stephen Zderic et al. eds., 2002).

140. For example, when a surgeon surgically creates a vagina, children must suffer through regular procedures on a lifetime basis where dilators must be inserted to maintain the vaginal structure. This has been described as a "routine sexual invasion." Irene Habich, Boy, Girl, Other: Intersex Advocates Call for Surgery Ban, Spiegel Online InT'L (Nov. 1, 2013), http://www.spiegel.de/international /germany/intersex-activists-call-for-ban-on-surgical-operations-on-children-a-931213.html [https:// perma.cc/97XF-JRE8].

141. Many, but "[n]ot all children with intersex conditions are sterilized. Some are born infertile, and some retain fertility after medical treatment." Anne Tamar-Mattis, Sterilization and Minors with Intersex Conditions in California Law, 3 Calif. L. Rev. Circuit 126, 129 (2012).

142. Juan E. Méndez, Report of the Special Rapporteur on Torture and Other Cruel, Inhuman or Degrading Treatment or Punishment II 76, U.N. Doc. A/HRC/22/53 (Feb. 1, 2013), http://www.ohchr.org/Documents/HRBodies/HRCouncil/RegularSession/Session22/A.HRC.22.53 _English.pdf [https://perma.cc/ZCU6-NR8F].

143. Id. II 88.

144. World Health Org., Eliminating Forced, Coercive and Otherwise Involuntary Sterilization: An InTERAgency Statement 7-8 (2014), http://apps.who.int/iris/bitstream /10665/112848/1/9789241507325_eng.pdf [https://perma.cc/YSC4-7FCL].

145. U.N. High Comm'r for Human Rts., Discrimination and Violence Against Individuals Based on Their Sexual Orientation and Gender Identity II 53 (May 4, 2015).

146. Council of Europe, supra note 103, at 19.

147. European Union Agency for Fundamental Rts., The Fundamental Rights Situation of InTersex People (Apr. 2015), http://fra.europa.eu/sites/default/files/fra-2015-focus-04 -intersex.pdf [https://perma.cc/NEA8-3A3K].

148. Comisión Interamericana de Derechos Humanos, Violencia Contra Personas 
also each called for a review of the unnecessary medicalization of intersex traits, which interfere with the individual's right to health, noting many of the human rights issues intersex people confront-forced sterilization; pain; incontinence; loss of sexual sensation; and lifelong mental suffering, including depression. Recognizing the adverse effect on physical integrity and autonomy, the recommendation was to cease genital-normalization surgery without the consent of the affected person.

I59 In the same year, 2015, the Astraea Lesbian Foundation for Justice established the first Intersex Human Rights Fund supporting organizations, projects, and campaigns led by intersex activists working worldwide to ensure the human rights, bodily autonomy, physical integrity, and self-determination of people with intersex traits. ${ }^{149}$

I60 The African Commission on Human and Peoples' Rights, in 2016, also expressed concern over the treatment of intersex people, considering bodily integrity, autonomy, freedom, and security of the individual related to nonconsensual, medically unnecessary treatment of intersex infants, children, and adolescents. ${ }^{150}$

I61 The Asia Pacific Forum on National Human Rights Institutions, in its 2016 report, discussed the rights to physical integrity, nondiscrimination, recognition before the law, and effective remedies and redress. ${ }^{151}$

I62 German and Swiss ethics institutions have also reported on this issue. A Swiss National Advisory Commission on Biomedical Ethics report argues against genital-normalization surgery due to the effect on physical and psychological integrity, and advocates for the delivery of better psychosocial support. ${ }^{152}$ The Swiss report advocates that all "(non-trivial) sex assignment treatment decisions which have irreversible consequences but can be deferred should not be taken until the person to be treated can decide for him/herself." ${ }^{153}$ The report also suggest that questions of criminal sanctions for sex assignment interventions should be examined.

I63 The German Ethics Council reported that intersex people should be recognized, supported, and protected from discrimination. ${ }^{154}$ Noting the importance of the right to physical integrity, preservation of sexual and gender identity, and right

Lesbianas, Gay, Bisexuales, Trans e Intersex en América (Nov. 12, 2015), http://www.oas.org/es /cidh/informes/pdfs/ViolenciaPersonasLGBTI.pdf [https://perma.cc/5MWT-G4FT].

149. Introducing the Intersex Fund Team at Astraea!, Astraea Lesbian Found. For Just. (June 16, 2015), http://www.astraeafoundation.org/news/344/60/Introducing-the-Intersex-Fund -team-at-Astraea [https://perma.cc/J9WH-SHC7].

150. African Comm'n on Human \& People's Rts., Report on the Civil, Political and Socio-Economic Rights of Transgender and Intersex Persons in South Africa Under the African Charter on Human and Peoples' Rights in Response to the Second Combined Periodic Report of the Government of South Africa and the Initial Report Under the Protocol to the African Charter on the Rights of Women in Africa (Apr. 2016), http://genderdynamix.org .za/wp-content/uploads/ACHPR-Transgender-and-Intersex-Shadow-Report-April-2016.pdf [https:// perma.cc/QFU6-YPWX].

151. Promoting and Protecting Human Rights in Relation to Sexual Orientation, Gender Identity and Sex Characteristics, APF: Asia PAC. F. OF NAT'L Human RTs. Insts. (June 2016), http://www .asiapacificforum.net/resources/manual-sogi-and-sex-charactersitics/.

152. Swiss Nat'l Advisory Comm'n on Biomedical Ethics, supra note 15, at 1.

153. Id. at 18.

154. German Ethics Council, Intersexuality: Opinion 125 (Feb. 23, 2012), http://www .ethikrat.org/files/opinion-intersexuality.pdf [https://perma.cc/K2FW-HE9B]. 
to an open future and procreative freedom, the German Ethics Council recommended that irreversible medical sex assignment in persons of ambiguous gender should be taken only by the individual concerned; in the case of a minor, the Ethics Council stated that

[i]n the case of an affected individual who has not yet attained decision-making capacity, such measures should be adopted only after thorough consideration of all their advantages, disadvantages and long-term consequences and for irrefutable reasons of child welfare. Such a reason at any rate applies if the measure concerned serves to avert a grave concrete risk to the life or physical health of the affected individual. ${ }^{155}$

I64 While these various reports and recommendations are all positive steps for the human rights of individuals with intersex traits, it is the enactment, codification, and administration of human rights protections that is vital in each country's judicial opinions, statutes, and regulations. This process has been more measured. ${ }^{156}$

\section{Annotated Bibliography}

Bird, Jo. "Outside the Law: Intersex, Medicine and the Discourse of Rights." Cardozo Journal of Law \& Gender 12 (2005): 65-80.

The premise of this article rests on the notion that one must have a classifiable sex to be considered as a human by the law. Bird argues that an intersex child-born without a classifiable sex-is not considered human, and therefore the human rights of the intersex child are regarded as nonexistent. She evaluates the applicability of international human rights discourse to intersex individuals, particularly the regulation of medical ethics under international law. Bird concludes that human rights law has failed to make a space for intersex individuals, rendering them invisible to the law and the human rights violations against them unrecognized.

Ehrenreich, Nancy, and Mark Barr. "Intersex Surgery, Female Genital Cutting, and the Selective Condemnation of 'Cultural Practices." Harvard Civil Rights-Civil Liberties Law Review 40 (2005): 71-140.

Over the last twenty-five years, opponents of female genital mutilation (FGM) have successfully lobbied to have the practice banned by federal statute in the United States, formally condemned by the United Nations, prohibited by many European countries, and deemed illegal in a majority of the countries where it is commonly practiced. Yet, FGM opponents fail to recognize a different type of genital cutting that occurs in their well-developed countries. This article challenges the mainstream anti-FGM activists' refusal to embrace intersex causes. The authors argue that the plight of the two communities are similar; genital-normalization surgeries parallel the cultural FGM surgeries in that they are largely medically unnecessary and result in similar side effects such as sexual dysfunction. While both practices are rooted in cultural behavior, the selective condemnation of the anti-FGM discourse is grounded upon Western/North American exceptionalism. The intersection of these two issues, the authors argue, demonstrates the "pitfalls of narrow, group-focused activism" (p.79).

155. Id. at 164 .

156. See infra "Foreign Approaches to Intersex Rights," III 73-83, for country-specific action. 
Holmes, Morgan. "Distracted Attentions: Intersexuality and Human Rights Protections." Cardozo Journal of Law \& Gender 12 (2005): 127-33.

This article discusses the reasons why intersexuality has been primarily considered a medical issue rather than a fundamental human rights concern. The author examines two of the first "identifiable official document[s]" (p.127) that address the treatment of intersex individuals as an issue of human rights: a report by the San Francisco Human Rights Commission and a Colombia Constitutional Court decision. Holmes advances the idea that not only should intersex be considered principally a human rights issue, but more narrowly, as a children's rights issue.

\section{Intersex Activist Movement}

\section{Intersex Activist Movement Generally}

I65 Intersex organizations and activist groups have been in existence since the mid-1980s. The groups concentrate on providing peer and family support and addressing health concerns and human rights. In the United States, there are several such organizations: Accord Alliance, ${ }^{157}$ interACT Advocates for Intersex Youth, ${ }^{158}$ and Organization Intersex International USA (OII-USA). ${ }^{159}$ These organizations all support the goal of ending the medical standard of cosmetic, nonconsensual genital "normalizing" surgeries. There are many foreign and international organizations as well.

I66 Since 2011, three International Intersex Forums have been held, supported by the ILGA (International Lesbian, Gay, Bisexual, Trans and Intersex Association) and ILGA-Europe. Intersex activists and organizations from all over the globe convened and released joint statements about human rights and bodily autonomy. In 2013, the third statement advocated for a cessation of genital-normalization surgeries. ${ }^{160}$ Intersex activists have frequently been disfigured and suffered trauma from genital surgeries themselves; they advocate that these surgeries end, or at least that decisions be postponed, in the face of normative standards and cultural pressure. The position held by these organizations is that intersexuality is not an anomaly that needs to be met with an automatic "fix."

157. Accord Alliance (http://www.accordalliance.org/) took the place of the Intersex Society of North America (http://www.isna.org/).

In 2007, ISNA sponsored and convened a national group of health care and advocacy professionals to establish a nonprofit organization charged with making sure the new ideas about appropriate care are known and implemented across the country. This organization, Accord Alliance, opened its doors in March, 2008, and will continue to lead national efforts to improve DSD-related health care and outcomes.

Dear ISNA Friends and Supporters, supra note 34.

158. InterACT Advocates for Intersex Youth (http://interactadvocates.org/) works to raise intersex visibility, empowering young intersex advocates and promoting laws and policies that protect intersex youth. It was formerly known as Advocates for Informed Choice.

159. Organization Intersex International (http://oii-usa.org/) is a multi-gendered, multiorientation, multi-racial NGO working for human rights for intersex people, particularly the rights to bodily integrity, self-determination, legal recognition, and depathologization of intersex traits and nonbinary identities in medicine and society. Its goal is to create a world where all intersex people are viewed and treated equally.

160. Public Statement by the Third International Intersex Forum, OII Europe (Dec. 1, 2013), http://oiieurope.org/public-statement-by-the-third-international-intersex-forum/ [https://perma.cc /8QH3-5LHY]. 
I67 Intersex activists argue that while psychosocial reasons are often the reason given to perform genital-normalization surgery, this type of treatment is socially driven and, therefore, ethically questionable. When surgery and hormone treatments are considered, healthcare professionals must ask themselves whether they are truly needed for the benefit of the child or are being offered to allay parental distress. ${ }^{161}$

I68 Intersex activists have worked tirelessly to educate society about these issues. They have publicized their stories via mass media, reaching many people; they have also connected with the healthcare industry by working with researchers, presenting at medical conferences, and reaching out to medical students. ${ }^{162}$ While it may appear that this work will succeed and one day eradicate, or at least limit, nonconsensual genital "normalizing" surgeries, the formation of new standards of care take a long time to impact actual medical practices. ${ }^{163}$ This slow evolution is taking too much time for much of the intersex community, who desire an immediate ban on genital-normalization surgery. This position is shared by many legal scholars. ${ }^{164}$

\section{Annotated Bibliography}

Hupf, Robert. "Allyship to the Intersex Community on Cosmetic, Non-Consensual Genital 'Normalizing' Surgery." William \& Mary Journal of Women and the Law 22 (2015): 73-104.

Hupf first acknowledges the difficult role that encompasses being an ally to any given community. Acting as an ally requires an individual to place the lived experiences of harmed individuals at the forefront of any movement and requires a challenging balancing act between enthusiastic goals and the immediate needs of the community's individuals. Hupf asserts that the intersex community continues to call for a moratorium on all cosmetic, nonconsensual genital-normalizing surgeries as its main objective. This article explores this proposal, as well as alternate proposals by intersex activists, allies, and other scholars. Through examination of the adoption and implementation of several of the proposed solutions, Hupf argues, "[u]ntil there is a prohibition on the practice of cosmetic, non-consensual genital normalizing surgery, proposals for an alternative solution must take a step back" (p.104).

Preves, Sharon E. "Out of the O.R. and into the Streets: Exploring the Impact of Intersex Media Activism." Cardozo Journal of Law \& Gender 12 (2005): 247-88. This article traces the history of the intersex movement and explores the role of mass media in the increased recognition of the intersex identity. Preves focuses on one organization in particular, the Intersex Society of North America (ISNA). Preves identifies ISNA as one of the pioneers of the intersex movement, highlighting the organization's polarizing transition from peer support group to political activist group. Preves credits ISNA and its use of mass media as a tool for advancing their political platform for the increased awareness of intersex issues. Preves

161. What Does INSA Recommend for Children with Intersex?, ISNA: INTERSEX Soc'y OF NoRTH AM., http://www.isna.org/faq/patient-centered [https://perma.cc/N3GG-83MA].

162. What's the History Behind the Intersex Rights Movement?, ISNA: InTERSEx Soc'y OF NoRTH AM., http://www.isna.org/faq/history [https://perma.cc/Q8A9-7QZB].

163. Anne Tamar-Mattis, Exceptions to the Rule: Curing the Law's Failure to Protect Intersex Infants, 21 BERKELEY J. GENDER L. \& JUST. 59, 78 (2006).

164. Id. 
admits that this recognition is not without controversy, foreshadowing the movement's tensions over where discourse of the intersex people belongs.

Stone, Moonhawk River. "Approaching Critical Mass: An Exploration of the Role of Intersex Allies in Creating Positive Education, Advocacy and Change." Cardozo Journal of Law \& Gender 12 (2005): 353-66.

This article is borne out of the author's personal experience as an ally working on behalf of intersex people. Stone maintains that the current tightrope that allies must walk-advocating for the interests of the group and gathering emotional information regarding injustices, while recognizing the limitations of personally understanding an individual's struggles - requires a careful balancing of attitudes and behaviors to facilitate effective advocacy. Since intersex people are only a small percentage of the population, Stone argues that allies will be crucial to the intersex movement.

\section{Intersection with Other Movements: LGBT and Same-Sex Marriage}

I69 The general public has been made more aware of the variations of gender and sexual orientation due to the LGBT and same-sex marriage movements. With the increased openness about sexual orientation and the growing visibility of the LGBT community and their challenge to expectations about gender roles and identity, there has been increasing social acceptance for individuals who do not fit the traditional classifications of gender and sexuality. This awareness that sexual anatomy does not dictate an individual's gender identity or sexual orientation has benefited the intersex movement's progress. "[T] ransgender ${ }^{165}$ identity [is] far less of a story than it used to be," ${ }^{166}$ while intersexuality is now the more marginal classification, in need of increased public awareness.

I70 However, the transgender community and the intersex community sometimes have disparate objectives. The intersex community's focus is not about making decisions on whether to have surgical intervention to "normalize" their bodies to their correct gender; the concern is about decisions regarding their biology being made with a lack of consent on their part. ${ }^{167}$ This has created some worries among the intersex community about the development of LGBT groups that include an "I" for the inclusion of persons with intersex traits. Other concerns are that including the "I" would encourage the public to assume that individuals with intersex traits should automatically be considered lesbian, gay, bisexual, or transgender. ${ }^{168}$ Some fear that parents of intersex infants who might reach out for assistance and education would not do so with an LGBT group, and might even be more

165. Transgender is "[a]n umbrella term for people whose gender identity and/or gender expression differs from what is typically associated with the sex they were assigned at birth." GLAAD Media Reference Guide-Transgender, GLAAD, http://www.glaad.org/reference/transgender [https:// perma.cc/V8VZ-PNZE].

166. Greenhouse, supra note 10.

167. Noa Ben-Asher, The Necessity of Sex Change: A Struggle for Intersex and Transsex Liberties, 29 HARV. J.L. \& GENDER 51, 51 (2006) ("Transsex individuals often desire the future body that they should have, while intersex individuals often mourn the body they had before an unwarranted normalizing surgery interfered with it.").

168. Intersex individuals, like all people, have various sexual orientations and gender identities. Paulo Sampaio Furtado et al., Gender Dysphoria Associated with Disorders of Sex Development, 9 Nat'L Rev. Urology 620, 622 (2012). Furtado states that between 8.5\% and 20\% of individuals with intersex traits may realize gender dysphoria due to their sex assignment at birth; this figure is dependent on the type of DSD. Id. at 626. 
likely to advocate for genital normalization for their children out of fear about their later sexuality or gender identity. ${ }^{169}$ Intersex activists are also concerned that their identity would be lost if joined with the larger LGBT movement, and believe that it is critical that the intersex movement gain visibility and provide specific resources for their own community. ${ }^{170}$

I71 Despite divergent paths, the transgender movement and the intersex movement do intersect in some ways. In both movements, individuals find their bodies are pathologized in a way analogous to the way psychiatry viewed homosexuality decades ago. Transgender individuals may still find themselves categorized as having a "gender identity disorder." From this perspective, intersexuality is simply a different sexual minority that is considered "abnormal" and is pathologized. ${ }^{171}$

I72 Another similarity in both movements is that surgical intervention for intersexuality is prompted by prejudice, discrimination, and fear of homosexuality. Our society's healthcare system determines the functionality of male and female genitals by the ability to engage in heterosexual intercourse. ${ }^{172}$ The fact of the matter is that the LGBT movement, same-sex marriage movement, and other social movements have all helped spur on the intersex movement. Social change requires evolution, and whatever the sequence, it is clear that diverse expressions of gender and sexuality are becoming more accepted and mainstream.

\section{Annotated Bibliography}

Ben-Asher, Noa. "The Necessity of Sex Change: A Struggle for Intersex and

Transsex Liberties." Harvard Journal of Law \& Gender 29 (2006): 51-98.

This author examines the tensions between intersex and transsex advocacy groups by deconstructing each group's distinct advocacy goal and the medical-scientific theories employed to support them. The transsex movement generally promotes surgeries and, more specifically, seeks to obtain Medicaid coverage for sex reassignment medical procedures. In contrast, the intersex movement generally opposes surgeries and calls for a moratorium on genital-normalization procedures on intersex infants and young children. At the center of the controversy is the distinction between sex and gender, the subject of a two-sided ongoing medical-scientific debate. Ben-Asher describes the main litigation propositions and structures of the two movements as the "legal representations of opposing medical positions and (perhaps more importantly) experts who have been challenging each other for years regarding meanings of sex and gender" (p.90). The author advances the idea that both movements should sever their reliance on medical-scientific theories and instead formulate legal arguments based on positive and negative liberties. According to Ben-Asher, this shift in framework would not only reconcile the two movements, but also liberate their respective legal arguments from the control of the scientific community.

169. Emi Koyama, Adding the "I": Does Intersex Belong in the LGBT Movement?, InTERSEX INITIATIVE, http://www.intersexinitiative.org/articles/lgbti.html [https://perma.cc/E2V9-HRYH].

170. Id.

171. Id.

172. Id. 
Cruz, David B. “Getting Sex 'Right': Heteronormativity and Biologism in Trans and Intersex Marriage Litigation and Scholarship.” Duke Journal of Gender Law \& Policy 18 (2010): 203-22.

This essay provides an extensive overview of U.S. judicial decisions in marriagerelated cases that turn on the legal recognition of a litigant's sex change. The author criticizes the majority of the lawyers' arguments and judicial opinions as either advancing heterosupremacy or reinforcing the notion of sex as a biological fact by ignoring the root of the legal issue. According to the author, the greater issue here is the use of sex as a regulatory tool to determine what identities and relationships to legally recognize. He further condemns the academic realm for limited-scope investigations that fail to consider the larger circumstances and continue to give the control of legal determinations to the medical community. The author argues, "It misdirects our focus, to someone's political detriment, to appeal to the natural or to 'the facts' of sex (as proclaimed by medical practitioners) as the basis for what are really political judgments about what identities and relationships to recognize" (p.217).

Greenberg, Julie A. "Intersex and Intrasex Debates: Building Alliances to Challenge

Sex Discrimination.” Cardozo Journal of Law \& Gender 12 (2005): 99-116.

This article examines two sources of tensions relating to intersex activists: the "intrasex debate" and "intersex disagreements" (p.102). The intrasex debate stems from the intersex community's wide separation on the issue of whether to call for a complete moratorium on all infant intersex surgeries. Intersex disagreements encompass the intersex movement's interactions with other activist groups related to sex and gender discrimination and specifically the conflicts that arise from decisions about whether to form alliances with certain groups. Greenberg argues that the intersex movement, to endure as a successful social justice movement, must embrace other groups that share a common goal of ending sex and gender discrimination.

Kajstura, Aleks. "Sex Required: The Impact of Massachusetts' Same-Sex Marriage Cases on Marriages with Intersex and Transsexual Partners." Cardozo Journal of Law \& Gender 14 (2007): 161-84.

In this student note, the author considers the application of same-sex marriage statutes in cases involving a transsex or intersex party and the unintended and often unreasonable outcomes that follow. Through her analysis of two leading Massachusetts cases, the author concludes that even a legal right to same-sex marriage may fail to consider the rights of transsex and intersex individuals. The author argues that the most comprehensive solution to this problem would be the elimination of a binary legal system of sex and gender.

Kogan, Terry S. “Transsexuals, Intersexuals, and Same-Sex Marriage.” BYU Journal of Public Law 18 (2004): 371-418.

By looking at a series of marriage cases involving a transsexual or intersex individual, Kogan sets out to challenge the assumption that an opposite-sex marriage requirement is easily enforced. Kogan argues that "these cases illustrate the difficulty and even foolishness in looking to a person's sex as a criterion for marriage" (p.371). Kogan specifically highlights several insights from the transsexual and intersexual marriage cases. For example, Kogan deduces that the determination of an individual's sex is not related to the goals of marriage and does not help a court enforce legal prohibitions against same-sex marriage. Kogan concludes that the ultimate lesson derived from the transsexual and intersexual marriage cases is that marriage should be available to all couples. 
Rosin, Michael L. "Intersexuality and Universal Marriage." Law \& Sexuality: A Review of Lesbian, Gay, Bisexual and Transgender Legal Issues 14 (2005): 51-133.

Rosin traces the history of intersexuality alongside the history of the courts' attempts to define sex in the context of marriage cases. Rosin highlights two courts that use different single-factor tests to determine whether an individual should be classified as a woman or a man. The single-factor approach, Rosin argues, is not always decisive and can have unintended legal consequences. The author argues that sex is analogous to race and is thus a social construct that cannot be confined to clear-cut categories. Rosin advances the concept of 'universal marriage, the right of any two unmarried (not closely related) adult persons to marry each other and enjoy the legal benefits (and obligations) of marriage regardless of the genital activities made possible and impossible by their sexual anatomies" (pp.56-57).

\section{Foreign Approaches to Intersex Rights}

\section{Discrimination}

I73 Individuals with intersex traits are frequently stigmatized and suffer a variety of human rights abuses. The international community has been working effectively to change standards on an international level. Presently, four countries protect "intersex" people from discrimination: South Africa, Australia, the island of Jersey, and the United States (on a very limited basis); three other countries protect such discrimination on the grounds of "sex characteristics": Malta, Greece, and Bosnia-Herzegovina.

I74 In South Africa, which expressly protects against sex discrimination in its constitution, the Judicial Matters Amendment Act, 2005 amended the Promotion of Equality and Prevention of Unfair Discrimination Act, 2000 (Act 4 of 2000) to incorporate intersex within its definition of sex. ${ }^{173}$ The Promotion of Equality and Prevention of Unfair Discrimination Act begins with a schedule of definitions, and two new definitions were added: (1) "sex" includes "intersex," and (2) "intersex means a congenital sexual differentiation which is atypical, to whatever degree." This change made intersex part of the meaning of "sex" in the equality clause, thus protecting intersexual individuals from discrimination.

I75 In Australia, “intersex status” was added in 2013 as a protected biological attribute in the Sex Discrimination Amendment (Sexual Orientation, Gender Identity and Intersex Status) Act on August 1, 2013, differentiating intersex status from sexual orientation, gender identity, and sex. ${ }^{174}$ This legislation protects intersex individuals as a stand-alone prohibited ground of discrimination. ${ }^{175}$ Similarly, the island of Jersey added "intersex status" to its definition of sex in $2015 .{ }^{176}$ Since discrimination on the basis of sex is prohibited, intersex status is protected in Jersey.

173. Judicial Matters Amendment Act 22 of $2005 \$ 16$.

174. Sex Discrimination Amendment (Sexual Orientation, Gender Identity and Intersex Status) Act 2013, (Cth) s 4(1).

175. U.N. Office of the High Comm'r for Human Rts., supra note 122.

176. States of Jersey (2015), Discrimination (Sex and Related Characteristics) (Jersey) Regulations 201, sched. 1, para. 7.3; see also Dan Christian GHattas, Standing Up For the Rights of InTERSEX PeOPLE 15 (Dec. 2015), http://www.ilga-europe.org/sites/default/files/how_to_be_a_great _intersex_ally_a_toolkit_for_ngos_and_decision_makers_december_2015_updated.pdf [https:// perma.cc/7ZSJ-XBL5]. 
I76 The United States issued a much narrower protection when the U.S. Department of Health and Human Services provided a response to a comment clarifying section 1557 of the Affordable Care Act. ${ }^{177}$ This response stated that when dealing with health programs administered by the Department of Health and Human Services, "the prohibition on sex discrimination extends to discrimination on the basis of intersex traits or atypical sex characteristics." 178

I77 In 2015, Malta adopted the Gender Identity, Gender Expression and Sex Characteristics (GIGESC) Act that protects intersex individuals from discrimination on grounds of "sex characteristics."179 The Maltese act states that "public service has the duty to ensure that unlawful sexual orientation, gender identity, gender expression and sex characteristics discrimination and harassment are eliminated, whilst its services must promote equality of opportunity to all, irrespective of sexual orientation, gender identity, gender expression and sex characteristics." 180

I78 The GIGESC Act was a landmark piece of legislation in Europe. ${ }^{181}$ Greece $^{182}$ and Bosnia-Herzegovina ${ }^{183}$ also categorize "sex characteristics" as a prohibited basis of discrimination.

\section{Genital Surgery Practices}

I79 Colombia and Malta have legally addressed the practice of nonconsensual genital surgery. The United States currently has a pending court case that addresses this issue and will likely be litigated in 2017. ${ }^{184}$

I80 The Constitutional Court in Colombia addressed this issue judicially by considering consent standards for such surgery with the country's constitution and

177. InterACT, Federal Government Bans Discrimination Against Intersex People in Health Care, InTERACT Blog (May 23, 2016), http://interactadvocates.org/federal-government-bans -discrimination-against-intersex-people-in-health-care/ [https://perma.cc/L6FZ-3C7L].

178. Nondiscrimination in Health Programs and Activities, 81 Fed. Reg. 31389 (May 18, 2016).

179. Individuals with intersex traits are covered under the language of "sex characteristics" because "[i]ntersex people are born with sex characteristics (including genitals, gonads and chromosome patterns) that do not fit typical binary notions of male or female bodies." Gender Identity, Gender Expression and Sex Characteristics Act of 2015, No. XI. This act also acknowledges a right to bodily integrity and physical autonomy; U.N. Office of the High Comm'r for Human Rts., supra note 122; see also infra "Genital Surgery Practices," III 79-83.

180. Gender Identity, Gender Expression and Sex Characteristics Act of 2015 II 2.

181. Malta Adopts Ground-Breaking Trans and Intersex Law, TGEU: Transgender Europe (Apr. 1, 2015), http://tgeu.org/malta-adopts-ground-breaking-trans-intersex-law/ [https://perma .cc/9DAC-P5UG].

182. Ilga-Europe, Annual Review of the Human Rights Situation of Lesbian, Gay, Bisexual, Trans and Intersex People in Europe 12 (May 2016), http://www.ilga-europe.org/sites /default/files/Attachments/annual_review_2016-for_web.pdf [https://perma.cc/K8XB-DP4U]; see also GHATTAs, supra note 176 , at 15 .

183. ILGA-Europe, supra note 182, at 49; see also Anti-Discrimination Law UpdatedGreat Step Forward in Bosnia and Herzegovina, ILGA Europe (July 14, 2016), http://ilga-europe.org /resources/news/latest-news/anti-discrimination-law-updated-bosnia-herzegovina [https://perma .cc/TG9S-ZKBP]; Bosnia \& Herzegovina Amends Its Anti-Discrimination Law; Intersex People Offered Protection for the First Time, Equal RTs. Ass'n for W. Balkans \& Turk. (July 14, 2016), http://www .lgbti-era.org/latest-news/bosnia-herzegovina-amends-its-anti-discrimination-law-intersex-people -offered-protection-for-the-first-time [https://perma.cc/J7GB-F5MB].

184. See supra "Medical Intervention and Its Legal Framework-Constitutional Rights," III 26-31. 
international norms in mind. ${ }^{185}$ Originally, the court declared that genital surgery was an infringement on one's fundamental right to human dignity and gender identity, and it demanded that the patient him- or herself must provide the informed consent. ${ }^{186}$ In two later cases, ${ }^{187}$ the court's holding was narrowed, allowing informed written parental consent for children younger than five years old, if the doctors provided parents with detailed information about the risks and benefits of surgery, and time to deliberate. ${ }^{188}$ Even though the final holding does not safeguard the rights of the youngest citizens, the controversy was acknowledged, and a heightened level of consent was required by the court. ${ }^{189}$

I81 In 2015, Malta became the first country to legislatively prohibit medically unnecessary genital surgery and treatment on the sex characteristics of minors without their informed consent, strengthening the rights of intersex persons. ${ }^{190}$ The legislation acknowledges a right to bodily integrity and physical autonomy, and directly bans surgical intervention driven by social factors. The Maltese Parliament advises other states to reassess and reform their legislation similarly.

I82 Other countries and government entities have recognized the issues at stake but not taken any formal legal action, as can be seen in the government findings of Australia, Kenya, Chile, Argentina, and the United States. The Australian Senate, in 2013, issued a report recommending that genital-normalization surgery be deferred until the individual can give his or her own fully informed consent. ${ }^{191}$ A Kenyan court, in 2014, found that medical intervention on intersex infants should face regulation, but then punted the issue to Parliament, stating that Parliament was the proper body to administer these regulations. ${ }^{192}$ Chile's Ministry of Health ${ }^{193}$ and

185. Kate Haas, Who Will Make Room for the Intersexed?, 30 Am. J.L. \& Med. 41, 50 (2004). Colombian law provides much more protection for intersex children than current U.S. law. The Colombia Constitutional Court relied on the U.N. Convention on the Rights of the Child, one of the primary authorities used to challenge nonconsensual genital-normalization surgery. The United States has not ratified the U.N. Convention on the Rights of the Child. Id. at 66.

186. Id. at 49-55. In that case, in 1995, the "court ruled that doctors could not alter the gender of a patient, regardless of the patient's age, without the patient's own informed consent." $I d$. at 50 .

187. Julie A. Greenberg \& Cheryl Chase, Colombia's Highest Court Restricts Surgery on Intersex Children, INTERSEX Soc'y OF N. AM., http://www.isna.org/colombia/background.html [https:// perma.cc/VP78-XDH4] (synthesizing in English the three Colombian cases).

188. The court called for the institution of what could be called "exceptional informed consent" before the performance of sex-assignment surgery. Hofman, supra note 57, at 13-14.

189. Haas, supra note 185 , at 54 .

190. Kieran Guilbert, Surgery and Sterilization Scrapped in Malta's Benchmark LGBTI Law, ReuTERS. СOM (Apr. 1, 2015), http://www.reuters.com/article/us-gay-rights-malta-idUSKBNOMS4ZE20150401 [https:// perma.cc/LXM4-AMAS]; see also Malta Adopts Ground-Breaking Trans and Intersex Law, supra note 181.

191. Senate Community Affairs References Comm., Involuntary or Coerced Sterilization of Intersex People in Australia (Oct. 25, 2013) (Austl.), http://www.aph.gov.au /Parliamentary_Business/Committees/Senate/Community_Affairs/Involuntary_Sterilisation/Sec _Report/index [https://perma.cc/3BMJ-YSAT].

192. Baby "A" v. Atty. Gen., Kenyatta Nat'l Hosp., Petition No. 266 (H.C.K. 2013), http:// kenyalaw.org/caselaw/cases/view/104234/ [https://perma.cc/T2CR-TAGV].

193. Instruye Sobre Ciertos Aspectos de la Atencion de Salud a Ninos y Ninas Intersex, Circular No. 18 (Dec. 22, 2015), https://oii.org.au/wp-content/uploads/2016/01/Circular-08-22.12.15 -Instruye-Sobre-Ciertos-Aspectos-de-la-atencion-de-Salud-a-Ninos-y-Ninas-Intersex.pdf [https:// perma.cc/T7DL-ZKMR]; see also Michael K. Lavers, Chilean Officials Oppose Intersex Children "Normalization" Surgery, WASH. BLADE (Jan. 11, 2016), http://washingtonblade.com/2016/01/11 /chilean-officials-oppose-normalization-surgery-for-intersex-children/ [https://perma.cc/VJ7S-UUZF]. 
Argentina's National Institute Against Discrimination, Xenophobia and Racism ${ }^{194}$ (a government agency) acted in a similar fashion after examination of this matter.

I183 Most recently, the U.S. Department of State, on October 26, 2016, issued a statement on Intersex Awareness Day, noting that intersex individuals "routinely face forced medical surgeries that are conducted at a young age without free or informed consent. These interventions jeopardize their physical integrity and ability to live free." 195 While the recommendations, reports, and statements above do not involve legal action or legislation, they do help to spread awareness of the human rights issues involved and show leadership while many individuals with intersex traits await stronger protections.

\section{Annotated Bibliography}

Beh, Hazel Glenn, and Milton Diamond. "Individuals with Differences in Sex Development: Consult to Colombia Constitutional Court Regarding Sex and Gender." Wisconsin Journal of Law, Gender \& Society 29 (2014): 421-45.

In 2012, author Milton Diamond received a consultation request from the Constitutional Court of Colombia regarding the case of an intersex individual and the Colombia system of national registration. The questions posed by the Colombia court related to the gender binary, such as whether the state should recognize a category other than male and female, and who would be in the best position to decide an individual's categorical placement. In this article, Diamond and co-author Hazel Glenn Bah expand on the answers provided to the Colombian courts. The article also explores recent changes in Nepal and Germany, such as the right to self-identify and the right to select an indeterminate sex designation on birth records, respectively.

Bochenek, Michael, and Kyle Knight. "Establishing a Third Gender Category in Nepal: Process and Prognosis.” Emory International Law Review 26 (2012): $11-41$.

This article centers on the decision in Pant v. Nepal, the landmark case that declared full, fundamental rights for all sexual minorities in Nepal and legally established a third gender category. The authors focus on the implementation of the new policy, comparing the process to other countries that have changed sex and gender documentation (e.g., Australia, India, New Zealand, and Pakistan). Highlighting some of the early challenges in Nepal, the authors write, "The bureaucratic processes of implementing an identity-based third gender category shed light on the complexity of such a category existing in a society" (p.34).

194. Instituto Nacional contra la Discriminación, la Xenofobia y el RacismoDocumento Temático INADI: Intersexualidad (2015), https://100porciento.files.wordpress .com/2015/07/intersexualidadinadi.pdf [https://perma.cc/DM2S-5DAD].

195. U.S. Dept. of State Recognition, INTERSEX DAY, http://intersexday.org/en/state-dept -recognition-2016/ [https://perma.cc/ZM8V-BBVD]. Intersex Awareness Day is internationally celebrated on October 26 to bring attention to human rights issues faced by intersex people. INTERSEX DAY, http://intersexday.org/en/ [https://perma.cc/A6PG-7DTL]. 
Gurney, Karen. “Sex and the Surgeon's Knife: The Family Court's Dilemma . . . Informed Consent and the Specter of Iatrogenic Harm to Children with Intersex Characteristics." American Journal of Law \& Medicine 33 (2007): 625-61.

This article provides a comprehensive look at a series of Australian High Court opinions involving the doctrine of informed consent, specifically where a parent or guardian is acting on behalf of a child. After exploring a number of different circumstances invoking this doctrine, Gurney surmises that the only credible basis for the judicial involvement of the Family Court is when irreversible surgical procedures, such as sex assignment surgery, are involved. Gurney argues that parents cannot be allowed to consent for sex assignment surgeries because there is no definitive way to determine the child's innate sexual identity. According to Gurney, the risk of error is therefore too high to justify surgeries in the absence of an immediate threat to life.

Haas, Kate. "Who Will Make Room for the Intersexed?" American Journal of Law \& Medicine 30 (2004): 41-68.

After noting the lack of case law available in the United States, the author surveys three Colombian court cases involving the legality of genital reconstruction surgeries performed without the child's consent. The cases resulted in a new standard for parental consent, one that prohibits parental consent for genital reconstruction on children over the age of five. In regard to decisions made on behalf of intersexed children under five years old, Colombian law now requires parents to be fully informed prior to giving consent. The author urges the United States to follow Colombia's lead in addressing the situation, but to take it one step further by prohibiting genital reconstruction surgeries altogether.

Rellis, Jennifer. "Please Write "E” in This Box': Toward Self-Identification and Recognition of a Third Gender: Approaches in the United States and India." Michigan Journal of Gender \& Law 14 (2008): 223-58.

Rellis's article tells the story of India's sexual minority group called the hijras. The hijras, a group composed of intersexed, transgendered, or transvestite men who identify as women, have undertaken efforts to engage in the political sphere by running for elected positions on an antidiscrimination platform. Rellis credits the hijras' grassroots advocacy efforts with the increased recognition of a third gender in India, demonstrated by the inclusion of a third gender identity option on Indian passports. According to Rellis, India's third gender identity option is particularly noteworthy because it allows the individual to self-identity.

Thorn, Erin D. "Drop the Knife! Instituting Policies of Nonsurgical Intervention for Intersex Infants." Family Court Review 52 (2014): 610-21.

This article describes recent legislative changes to the treatment of intersex individuals in Germany and Colombia. In Germany, a law now provides the option to identify sex as "X" on an infant's birth certificate. Colombia has passed legislation that restricts a parent's ability to consent to infant genitalia surgeries and has recommended following Germany's lead in allowing for an intersex designation on birth certificates. Thorn also looks to advocacy efforts at the U.N. level and by the European Union to contrast the lack of action being taken to protect intersex children in the United States. After drawing attention to the efforts made by other countries to address the policy of infant intersex surgeries, Thorn concludes by urging the United States to follow suit. 


\section{U.S. Reform/Recommendations}

I84 Some scholars have proposed mandatory judicial oversight whenever parents pursue genital-normalization surgery for their child. ${ }^{196}$ This would assure the best interest of the child is the exclusive focus of a neutral decision maker, providing sufficient procedural and substantive due process protections. ${ }^{197}$ Another proposal is that a two-step approach be instituted that would necessitate guidance from an ethics board (including psychiatrists, pediatricians, and other relevant experts) and a recommendation by the court prior to any surgery. ${ }^{198}$ In her proposal, Julie Greenberg suggests that the board would provide an advisory opinion to the court, and the court would make the final determination. ${ }^{199}$ Greenberg's proposal also includes that a child advocate be appointed by the court to advocate for the child's interests. ${ }^{200}$ In the face of the above judicial oversight proposals, parents may argue that the U.S. Supreme Court acknowledges parents have a protected liberty interest in the way they raise their children under the Fourteenth Amendment ${ }^{201}$ however, this right has been found to have its limitations. ${ }^{202}$

$\mathbb{1} 85 \mathrm{It}$ is also possible that hospitals and physicians may take action to advocate for court review before performing genital-normalization surgeries, as they start to be aware of the increasing possibility of litigation by former patients who are dissatisfied with their surgery results. ${ }^{203}$ The criticisms of immediate surgery on infants have been made known more broadly, and, over time, it is becoming increasingly uncertain exactly what risks physicians are required to acknowledge to conform to the standard for informed consent. ${ }^{204}$

I86 Although unpopular in the legal literature, there are those scholars who argue that genital-normalization surgery, if requested by parents, should not be prohibited ${ }^{205}$ Instead, this minority of scholars argues primarily that parents need to be informed of known risks and different treatment options. ${ }^{206}$ Some scholars suggest a model that focuses largely on parental and familial needs, requiring doctors to openly discuss the intersex condition with parents, as well as inform parents of all available remedies from a neutral standpoint. ${ }^{207}$

I87 Some scholars believe that it is the legislature, not the judiciary, that is the appropriate venue for protecting infants "with any power or consistency." ${ }^{208}$ Scholars and intersex activists urge a complete legislative moratorium on early genitalnormalization surgeries on children, contending that parents lack the authority to

196. Hofman, supra note 57, at 11 .

197. Curtis, supra note 85 , at 849 .

198. GREENBERG, supra note 2, at 42.

199. Id.

200. Id. at 43 .

201. Meyer v. Nebraska, 262 U.S. 390 (1923).

202. These limitations are seen in cases concerning organ donation and sterilization of minors. Alison Davidian, Beyond the Locker Room: Changing Narratives on Early Surgery for Intersex Children, 26 Wis. J.L. GENDER \& Soc'y 1, 18 (2011).

203. Tamar-Mattis, supra note 163 , at 107-08.

204. Id. at 108 .

205. E.g., Laura D. Hermer, A Moratorium on Intersex Surgeries? Law, Science, Identity, and Bioethics at the Crossroads, 13 CARdozo J.L. \& Gender 255, 256 (2007).

206. Id.

207. Id. at 256-57.

208. Hofman, supra note 57, at 16. 
consent to these practices because they compromise the children's fundamental right to procreate and the right to bodily integrity. ${ }^{209}$ Children can manifest informed consent autonomously at a later time if they desire treatment. ${ }^{210}$

I88 Some scholars express concern that a moratorium avoids the issue of psychosocial damage to children with intersex traits who must wait for years until decision making becomes finalized. ${ }^{211}$ Other scholars believe that banning genitalnormalization surgeries without also pursuing reconstruction of our societal perspective toward sex and gender "puts the proverbial cart before the horse." 212 Scholars advocate legislation recognizing the right to self-identify as a third gender, while codifying the expansive judicial interpretations of Title VII in response to the increasing awareness of human biological variation. ${ }^{213}$ "Statutory reform in the U.S. can be an immediate remedy while advocates begin building a constitutional right to self-identify outside the gender binary based on the fundamental right to privacy and bodily integrity derived from the 14th amendment's Due Process Clause." ${ }^{214}$

I89 There has been a bit of attempted reform at the state legislative level. In 2016, Indiana State Representative Ed Clere proposed a bill focused on intersex children in state custody or under state supervision to prevent medically unnecessary surgery done to "normalize" a child's physical appearance. While Clere prevented the controversy between parental rights and children's rights from impeding this issue by focusing solely on children in state custody, he believes this will eventually be an unavoidable debate. ${ }^{215}$

\section{Annotated Bibliography}

Aliabadi, Sara A. "Gender Assignment Surgery for Intersexed Infants: How the Substantive Due Process Right to Privacy Both Supports and Opposes a Moratorium." Virginia Journal of Social Policy \& the Law 12 (2004): 170-96.

Looking through the lenses of the fundamental right to privacy, this student author asks whether the privacy doctrine supports or opposes a moratorium on early gender assignment surgery. Aliabadi ultimately concludes that proponents on both sides of the debate could use the privacy doctrine to support their

209. Beh \& Diamond, supra note 7 , at 59.

210. E.g., Uslan, supra note 104, at 304.

211. Robert M. Blizzard, Intersex Issues: A Series of Continuing Conundrums, 110 Pediatrics 616, 619 (2002).

212. Hermer, supra note 205, at 261 n.35.

213. Rellis, supra note 111, at 255.

214. Id. at 256-57.

215. Henriques, supra note 22. Clere's bill did not receive a hearing before the Committee on Family, Children and Human Affairs and died during the 2016 session. H. 1242, 2016 Sess. (Ind. 2016). The bill also provides that

A juvenile court having jurisdiction over the intersex child may allow the intersex child to provide consent for a gender differentiation procedure if:

(1) the intersex child has undergone an evaluation by:

(A) a psychologist; and

(B) a physician;

who are each experts in the treatment of intersex conditions;

(2) the intersex child has been provided full knowledge of the possible risks and benefits of the gender differentiation procedure; and

(3) the court believes that the intersex child has the maturity to provide informed consent. 
respective arguments. However, Aliabadi herself argues that the imposition of a moratorium would be premature and would fail to adequately protect the intersex individual as it would be grossly overinclusive in denying all intersexed infants the opportunity to undergo surgery until they were old enough to competently choose surgery for themselves.

Aliabadi, Sara A. "You Make Me Feel Like a Natural Woman: Allowing Parents to Consent to Early Gender Assignment Surgeries for Their Intersexed Infants." William \& Mary Journal of Women and the Law 11 (2005): 427-59.

The author acknowledges in her student note the complications and risks of gender assignment surgeries, recognizing that surgeries often fail the interests of the intersex individual, but nevertheless argues that a legal moratorium should not be placed on the surgeries. A "one-size-fits-all judgment" (p.429) by courts and legislators to impose a moratorium, she argues, would be "inappropriate, premature, and potentially harmful to a large number of individuals" (p.428). According to this analysis, parents, with the help of doctors and other medical professionals, are better suited to make a medical decision based on the needs of the specific intersexed individual. She supports her argument by examining the legal tradition of deference to parental wishes in regards to their ability to consent to medical procedures on behalf of their minor children.

Bishop, Emily A. "A Child's Expertise: Establishing Statutory Protection for Intersexed Children Who Reject Their Gender of Assignment." New York University Law Review 82 (2007): 531-68.

This student author utilizes juvenile law to propose a statutory framework that would allow intersex minors to consent to a gender transition, removing the necessity for parental consent. The framework would also include a provision equating any active parental interference with the child's desire to transition with neglect. Historically, minor consent laws regard a minor as competent to consent to certain medical treatments as long as the minor is aware of the procedure and the consequences, as well as any treatment alternatives. The author highlights that this model would presume that intersex minors could legally consent to counseling and to assistance with a social gender transition. The note's conclusion enumerates potential unresolved issues with this framework, but nonetheless maintains that it would be a step in the right direction.

Curtis, Skylar. "Reproductive Organs and Differences of Sex Development: The Constitutional Issues Created by the Surgical Treatment of Intersex Children." McGeorge Law Review 42 (2011): 841-72.

This article explores the legal approach to parental consent to certain medical treatments on behalf of individuals with mental disabilities who do not have the legal capacity to consent for themselves. Courts have held that parental consent is inadequate to authorize certain types of medical procedures for the mentally disabled, specifically procedures such as intentional sterilization that place a fundamental right at stake. In these circumstances, many states require a judicial hearing in which a third party is appointed to represent the interests of the minor child prior to the approval of the intentional sterilization. Curtis parallels infant intersex surgeries and the potential deprivation of the child's fundamental rights, ultimately arguing for the expansion of required judicial hearing procedures to protect intersex children. 
Davidian, Alison. "Beyond the Locker Room: Changing Narratives on Early Surgery for Intersex Children." Wisconsin Journal of Law, Gender \& Society 26 (2011): 1-22.

In this article, Davidian distinguishes between parental intentions and interests by raising the question of whose interests are actually being protected under an informed parental consent model. Looking further into the idea of parental consent, Davidian highlights the fact that the authority of parents to make medical decisions on behalf of their children is not absolute. Generally, parents are unable to authorize the sterilization of children without a court order, based largely on the rationale that the right to procreation is a fundamental right. The author argues that similar judicial approval should be required for intersex surgeries. Davidian acknowledges that the court may not prove a better decision maker, but argues that it will develop a better decision-making process. According to the author, "Moving the debate into the courtroom also has the potential to make public what has been shrouded in secrecy, behind a medical veil" (p.19).

Hermer, Laura D. "A Moratorium on Intersex Surgeries? Law, Science, Identity, and Bioethics at the Crossroads." Cardozo Journal of Law \& Gender 13 (2007): $255-72$.

Hermer responds to two proposals published in the Cardozo Journal of Law \& Gender's 2005 Symposium - one by Jo Bird and the other by Hazel Glenn Beh and Milton Diamond - which either advocate for, or would result in, a moratorium on intersex surgeries. Hermer believes both approaches fall short in addressing the deeper issues related to intersex surgeries, citing social and psychological reasons as examples. She also argues that either proposal would eliminate ongoing scientific research focused on intersex treatment practices. Hermer's own position is consistent with that of her earlier work and calls for greater counseling of the parents prior to any decision making. She thinks that parents need to be informed of the risks and benefits of a myriad of treatment options, including immediate and delayed "cosmetic" genital treatment options. According to Hermer, a parent should then be able to elect for their child's early "cosmetic" genital surgery.

Hermer, Laura. "Paradigms Revised: Intersex Children, Bioethics \& the Law." Annals of Health Law 11 (2002): 195-236.

This author argues for an approach to intersex treatment that balances the intersex individuals' rights (as expressed by intersex activists) with other concerns such as parental interests, cultural considerations, and family dynamics. Hermer first evaluates medical malpractice and informed consent actions, ultimately concluding that neither legal avenue will provide adequate relief for the intersex individual. In its place, Hermer proposes a model that focuses largely on parental and familial needs, which Hermer argues may be just as critical as the intersex individuals' needs. The model requires physicians to openly discuss the intersex condition with parents, as well as inform parents of all available remedies from a neutral standpoint. Hermer states that parents, together with the physician, should choose the gender of the child. Notably excluded from her model is any moratorium on infant surgeries, which Hermer believes should remain a treatment option for intersex infants.

Lloyd, Erin. "From the Hospital to the Courtroom: A Statutory Proposal for Recognizing and Protecting the Legal Rights of Intersex Children." Cardozo Journal of Law \& Gender 12 (2005): 155-95.

This student note contends that the most immediate and effective way to remedy the harms suffered by intersex individuals and change treatment protocol for 
the future is through legislation. Lloyd proposes a model statute that subjects intersex surgeries to judicial order, requiring a parent or guardian of an intersex individual to file an application for consent with a specific court. Among other requirements, the statute mandates the court to appoint an uninterested party to provide legal counsel to and represent the interests of the intersex child. Under the guidelines of the model statute, for a judgment to be entered in favor of surgery, the judge must find that: "(1) The surgery proposed is an accepted method within the particular field to address the intersex condition presented; and (2) That the proposed surgery is medically necessary to protect the health or life of the intersex child; and (3) That the potential benefits substantially outweigh the risks and potential adverse effects on the intersex child" (p.194).

Ouellette, Alicia. "Shaping Parental Authority over Children's Bodies." Indiana Law Journal 85 (2010): 955-1002.

This author illustrates the broad discretion afforded to parents through the personal narratives of four children who underwent medical and surgical interventions at the election of their parents. Ouellette is critical of the current legal model because it allows parents to subordinate their child's interests to their own. As an alternative legal model, Ouellette proposes a trust-based construct, in which parents are the trustees, bound by fiduciary duties to act on behalf of the child's best interest. Under Ouellette's framework, any decisions that might serve a parental interest at the expense of the child would be subjected to a neutral third-party review.

Tamar-Mattis, Anne. “Exceptions to the Rule: Curing the Law's Failure to Protect Intersex Infants.” Berkeley Journal of Gender, Law \& Justice 21 (2006): 59-110. Because genital-normalizing surgery is medically unnecessary and carries real risks of parental conflict of interest, the author proposes that courts should have jurisdiction to intervene and protect the fundamental rights of the infant in the same way they do for children who are potential organ donors or who face elective sterilization. Tamar-Mattis looks to these existing categorical exceptions for a model of decision making that she suggests will ensure independent consideration of the child's interests. Factors that make genital-normalizing surgeries an appropriate case for a categorical exception are noted, along with benefits and possible objections to the use of this model. The author argues that the categorical exception model provides a protective and proven structure for making difficult medical decisions affecting the fundamental rights of children when their parents face a conflict of interest, thus helping to ensure that intersex children's fundamental rights are protected until they have the ability to decide for themselves.

Uslan, Samantha S. "What Parents Don't Know: Informed Consent, Marriage, and Genital-Normalizing Surgery on Intersex Children.” Indiana Law Journal 85 (2010): 301-23.

In this student note, Uslan stresses the effects of gender-normalizing surgeries and their potential interference with a child's fundamental right to an open future, specifically the fundamental right to marriage. According to Uslan, parental consent to a child's surgery should not be allowed where the fundamental right of a child may be compromised by the decision. Further, she argues that even judicial oversight alone will not sufficiently protect the rights of intersex children. Instead, Uslan calls for a legislative ban on all genital-normalizing surgeries that are not consented to by the intersex individuals themselves, except in the case of a medical emergency. 


\section{Conclusion}

190 Recently, there has been heightened interest in the issue of intersexuality among government, nongovernmental organizations, and policymakers. The general public is exposed now to much more media coverage and human rights statements about intersexuality. The subject is of burgeoning interest in the legal arena. This annotated bibliography abstracts articles to provide a reference point as well as an understanding of the history of the scholarship in this area. As scholars continue to examine intersex issues and various strategies to abolish discriminatory systems, I plan to continue building this collection of articles. I fervently hope that scholars will continue to document the struggle and continue to propose solutions to enable the law to move forward to stop the unfortunate practices that have injured children with intersex traits. 